See discussions, stats, and author profiles for this publication at: https://www.researchgate.net/publication/327843423

\title{
Holocene chronostratigraphy of northeastern Baffin Bay based on radiocarbon and palaeomagnetic data
}

Article in Boreas · September 2018

Dol: 10.1111/bor.12346

CITATIONS

7 authors, including:

Myriam Caron

Université du Québec à Rimouski UQAR

4 PUBLICATIONS 17 CITATIONS

SEE PROFILE

Jean Carlos Montero-Serrano

Université du Québec à Rimouski UQAR

53 PUBLICATIONS 518 CITATIONS

SEE PROFILE

Some of the authors of this publication are also working on these related projects:

Environmental and land-use change in Sulawesi, Indonesia View project

Project

MARGES View project
READS

97

Guillaume St-Onge

Université du Québec à Rimouski UQAR

202 PUBLICATIONS 2,839 CITATIONS

SEE PROFILE

Andre Rochon

Université du Québec à Rimouski UQAR

145 PUBLICATIONS 5,100 CITATIONS

SEE PROFILE 


\section{BOREAS}

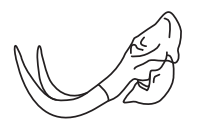

Caron, M., St-Onge, G., Montero-Serrano, J.-C., Rochon, A., Georgiadis, E., Giraudeau, J. \& Massé, G.: Holocene chronostratigraphy of northeastern Baffin Bay based on radiocarbon and palaeomagnetic data. Boreas. https://doi. org/10.1111/bor.12346. ISSN 0300-9483.

The northeastern Baffin Bay continental margin, which experiences high sediment accumulation rates, is an excellent location to study Holocene sedimentary variations. However, it is often difficult to obtain reliable chronologies of the sediment archives using traditional methods $\left(\delta^{18} \mathrm{O}\right.$ and radiocarbon) due to specific oceanographic conditions (e.g. corrosive bottom waters). Here we propose a chronostratigraphy of three cores collected on the northwestern Greenland margin (AMD14-204, AMD14-210 and AMD14-Kane2B) based on a combination of radiocarbon dating and palaeomagnetic records. Geophysical properties of discrete samples were used to verify the reliability of the palaeomagnetic records. Palaeomagnetic analyses indicate a strong and stable natural remanent magnetization carried by low coercivity ferrimagnetic minerals (magnetite) in the pseudo-single domain grain size range. Correlation of the full palaeomagnetic vector (inclination, declination, and relative palaeointensity) was used to establish a reliable chronostratigraphical framework for two of the cores (AMD14-204 and AMD14-210) and to propose an original palaeomagnetic record for the previously ${ }^{14} \mathrm{C}$-dated core AMD14-Kane2B that covers most of the Holocene. Overall, this new chronostratigraphy allowed improvement of the timing of the main palaeoenvironmental changes that occurred in this area during the Holocene.

Myriam Caron (myriam.caron03@uqar.ca), Guillaume St-Onge, Jean-Carlos Montero-Serrano and André Rochon, Institut des sciences de la mer de Rimouski (ISMER) Canada Research Chair in Marine Geology, Université du Québec à Rimouski and GEOTOP Research Center, 310 allée des Ursulines, Rimouski, QC G5L3A1, Canada; Eleanor Georgiadis and Jacques Giraudeau, CNRS, UMR EPOC, Université de Bordeaux, Allée Geoffroy Saint-Hilaire, Pessac 33615, France; Guillaume Massé, Département de Biologie, UMR CNRS 5805, Université Laval, Avenue de la Medecine, Québec, QC, Canada; received 18th April 2018, accepted 21st August 2018.

Baffin Bay is a key location to study ice-margin dynamics and changes in sea-surface conditions, notably for its proximity to the large ice sheets during the late Quaternary and its connection to the Arctic and North Atlantic oceans. Continental margin sediments, which usually accumulate at high rates, are particularly suited for highresolution palaeoenvironmental reconstructions. However, establishing a reliable chronostratigraphical framework in Arctic basins such as Baffin Bay using traditional dating methods (e.g. radiocarbon or oxygen isotopes; de Vernalet al. 1987; Andrewset al. 1998; Simon et al. 2012) has been challenging. In high-latitude marine sedimentary environments including Baffin Bay, fossil remains of carbonate producing micro- to macro-fauna such as foraminifera and molluscs are generally poorly preserved in hemipelagic sediments due to calcium carbonate dissolution (Aksu 1983; de Vernal et al. 1992; Azetsu-Scott et al. 2010). In addition, the formation and the sinking of high-density brines during sea-ice growth influence the $\delta^{18} \mathrm{O}$ signal and its derived stratigraphy (HillaireMarcel \& de Vernal 2008). It is, therefore, often necessary to use alternative methods to improve the chronostratigraphy of sediment collected in these environments.

An increasing number of palaeomagnetic studies has been published in the last decade in an effort to improve chronologies of late Quaternary sedimentary sequences and thus attesting to the benefit of using palaeomagnetism as a dating tool in the Arctic during the Holocene (e.g.
Barletta et al. 2008; Lisé-Pronovost et al. 2009; Antoniades et al. 2011; Ólafsdóttir et al. 2013; Beaudoin et al. 2016; Lund et al. 2016; Deschamps et al. 2018). Variations in inclination, declination, and relative palaeointensity have been used to build Holocene palaeomagnetic reference curves (e.g. 'Fennostack', Snowball et al. 2007; 'Eastern Canadian stack', Barletta et al. 2010; 'Greenland-Iceland PSV composite', Stoner et al. 2013). Recent studies revealed that the combined use of radiocarbon dates, palaeomagnetic secular variations (PSV) and geomagnetic model outputs can be used to establish the chronostratigraphy of Arctic Holocene sediment sequences (e.g. Barletta et al. 2010; Antoniades et al. 2011; Stoner et al. 2013; Lund et al. 2016; Caricchi et al. 2018). In this paper, the full-vector palaeomagnetic sequence of three sediment cores (AMD14-Kane2B, AMD14-204, AMD14-210) from the northwestern continental margin of Greenland, combined with radiocarbon dating, are compared to three other palaeomagnetic records (Barletta et al. 2010; Stoner et al. 2013; St-Onge \& St-Onge 2014) and a geomagnetic field model ('CALS10k.1b', Korte et al. 2011) in order to establish a reliable chronostratigraphy for this area.

\section{Regional setting}

Baffin Bay is an oceanic basin $1300 \mathrm{~km}$ long and $450 \mathrm{~km}$ wide located between Greenland and the Canadian Arctic 
Archipelago (CAA) with a water depth of up to $2300 \mathrm{~m}$ (Aksu \& Piper 1987). Baffin Bay is a pathway for fresh water and sea ice between the Arctic and North Atlantic oceans through the northern Nares and Barrow Straits and the southern Davis Strait (Fig. 1). The oceanographic circulation in Baffin Bay is counter-clockwise with the relatively warm and salty west Greenland current (WGC) flowing northward at intermediate depth (below meltwater at the surface) and the Baffin Island current, a cold surface current flowing southward along Baffin Island from northernmost Baffin Bay (Fig. 1, Tang et al. 2004). The WGC turns west in Melville Bay before joining the Baffin Island current in Smith Sound. However, it has been shown that a small branch of the WGC circulates up to Nares Strait at depths below $250 \mathrm{~m}$ (Sadler 1976; Tang et al. 2004). A shallow carbonate compensation depth (600 to $900 \mathrm{~m}$ ) causes intense carbonate dissolution and poor preservation of calcareous microfossils in Baffin Bay sediments (Aksu 1983; de Vernal et al. 1992). Furthermore, an extensive sea ice cover exists during most of the year, with minimal sea ice cover extent in September (Tang et al. 2004).

The bathymetry of Baffin Bay is asymmetrical, with a central abyssal plain surrounded by the large Greenland continental shelf $(250 \mathrm{~km})$ to the east, and a much narrower
Baffin Island continental shelf $(25-50 \mathrm{~km})$ to the west (Tang et al. 2004; Andrews et al. 2014). These continental shelves were geologically shaped by the large Greenland, Laurentian and Innuitian ice sheets (GIS, LIS and IIS, respectively) during the most recent glaciation, as demonstrated by the presence of cross-shelf trough systems that extend from the coast and out to the continental slope (e.g. Aksu \& Piper 1987; Ó Cofaigh et al. 2013; Slabon et al. 2016). During the glaciation, these three ice sheets enclosed on three sides the Baffin Bay. The straits in the CAA were blocked by ice until the retreat of the ice sheets during the deglaciation (Dyke et al. 2002; Briner et al. 2006; England et al. 2006). The opening of Nares Strait around 9 cal. ka BP allowed the connection between the Arctic and Atlantic oceans through Baffin Bay, which then permitted the establishment of the modern oceanographic circulation in Baffin Bay and in the Labrador Sea (England et al. 2006; Jennings et al. 2011; St-Onge \& St-Onge 2014).

Present-day sediments found on the Baffin Bay sea floor are mainly derived from glacial erosion of the surrounding Greenland and CAA landmasses: through the various sedimentary processes (e.g. ice-rafted debris (IRD), glacigenic debrisflows, meltwater plumes, turbidity currents) that are dominant in these environments (Marlowe 1966; Hiscott

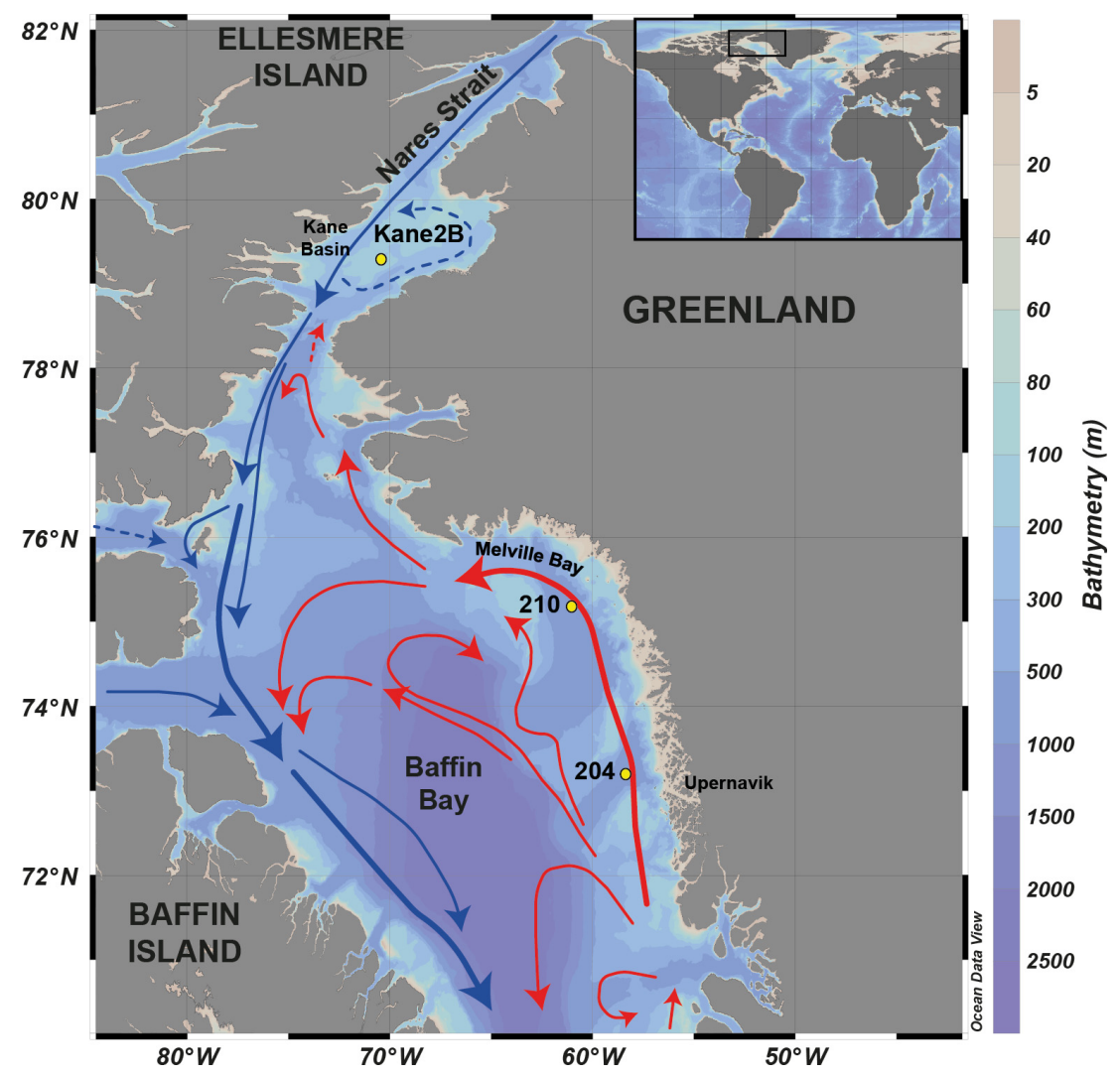

Fig. 1. Map of the Baffin Bay area and location of core AMD14-Kane2B, AMD14-210, AMD14-204 sampling sites (yellow spot). The general bathymetry and simplified oceanic circulation are also represented. Red arrows illustrate the relatively warm and salty water of the west Greenland current, whereas the blue arrows represent colder Arctic waters. 
et al. 1989; Ó Cofaigh et al. 2003; Simon et al. 2014, 2016). High sedimentation rates are typically found on highlatitude continental shelves and slopes and generally vary between 40 and $140 \mathrm{~cm} \mathrm{ka}^{-1}$ for northern Baffin Bay (e.g. Hamel et al. 2002; St-Onge \& St-Onge 2014).

\section{Material and methods}

\section{Coring sites}

Three sediment cores were collected on board the Canadian Coast Guard Ship (CCGS) icebreaker 'Amundsen' in northern Baffin Bay during the 2014 ArcticNet expedition (Leg 1b). Cores AMD14-204 and AMD14210 (hereinafter referred to as 204 and 210) are located on the northwest Greenland margin, in the cross-shelf troughs north of Upernavik Isstrøm and in Melville Bay, respectively, whereas core AMD14-Kane2B (hereinafter referred to as Kane2B) is located in the Kane Basin (Fig. 1, Table 1). The cores were collected using a Calypso Square (CASQ) gravity corer $(25 \times 25 \mathrm{~cm}$ wide-square section) and sections of up to $1.5 \mathrm{~m}$ long were subsampled on board with U-channel samples (plastic liners of $2 \times 2 \mathrm{~cm}$ cross-section). Due to its large surface, the CASQ corer minimizes sediment disturbance during coring compared to a regular piston-corer.

\section{Physical properties}

All sediment cores were run through a computerized axial tomography scan (CAT-scan) at the Institut national de recherche scientifique - Centre eau, terre et environnement (INRS-ETE, Quebec, Canada). The resulting digital X-ray images were (i) displayed in greyscale to visualize and identify the different sedimentary structures, and (ii) expressed as computed tomography (CT) numbers, which primarily reflect changes in bulk density (e.g. St-Onge et al. 2007; St-Onge \& Long 2009; Fortin et al. 2013).

In addition, the following parameters were determined on the U-channels at $1-\mathrm{cm}$ intervals with a GEOTEK Multi-Sensor Core Logger (MSCL) at the Institut des sciences de la mer de Rimouski (ISMER, Canada): wet bulk density, low-field volumetric magnetic susceptibility $\left(\mathrm{k}_{\mathrm{LF}}\right)$ and diffuse spectral reflectance. The reflectance was obtained by using a hand-held Minolta CM-2600d spectrophotometer and the sediment colour is expressed according to the $\mathrm{L}^{*}, \mathrm{a}^{*}$ and $\mathrm{b}^{*}$ colour space of the Commission Internationale de l'Eclairage (e.g. St-Onge et al. 2007).

\section{Grain-size analyses}

Grain-size data for core Kane2B were obtained at 2 to $4 \mathrm{~cm}$ resolution by Georgiadis et al. (submitted) using a Malvern 200 laser multisizer at EPOC-Université de Bordeaux (France), and a Beckman Coulter LS13320 laser diffraction grain size analyser $(0.04-2000 \mu \mathrm{m})$ was used at the Institut des sciences de la mer de Rimouski (ISMER, Canada) to analyse core 204 and 210 sediments at $8-\mathrm{cm}$ resolution. For cores 204 and 210, the sediment samples were pretreated with $10 \mathrm{~mL}$ hydrogen peroxide $\left(\mathrm{H}_{2} \mathrm{O}_{2} ; 30 \% \mathrm{v} / \mathrm{v}\right)$ and $10 \mathrm{~mL}$ hydrochloric acid $(\mathrm{HCl} ; 0.5 \mathrm{~N})$ for at least $72 \mathrm{~h}$ to remove the organic matter and carbonates. Sediment deflocculation was performed by successive washing with distilled water and the samples were disaggregated in a mechanical shaker for $12 \mathrm{~h}$ prior to particle size measurement. The grain-size distribution and statistical parameters were calculated using the GRADISTAT software (version 8; Blott \& Pye 2001) using the geometric $(\mu \mathrm{m})$ method of moments. Furthermore, IRD abundance was determined using the method described by Grobe (1987), which consists of counting the $>2 \mathrm{~mm}$ fraction on the X-ray image of the core (here, CAT-scan image).

\section{Bulk magnetic properties}

Hysteresis properties and backfield magnetic remanence of discrete samples (two to three samples per core section and in the different facies) were obtained using an alternating gradient force magnetometer (MicroMag 2900 from Princeton Measurements Corporation ${ }^{\mathrm{TM}}$ ) on samples collected from selected intervals in each core section and representing the different lithological facies present in the three cores. The hysteresis parameters: saturation magnetization (Ms), coercive force $(\mathrm{Hc})$, saturation remanence (Mrs) and coercivity of remanence (Hcr) were determined using the data from the hysteresis loops and backfield remanence curves. Magnetic grain-size proxies were then calculated as ratios $\mathrm{Mrs} / \mathrm{Ms}$ and $\mathrm{Hcr} / \mathrm{Hc}$ and reported in a biplot of these ratios (Day et al. 1977).

\section{Palaeomagnetic analysis}

The continuous palaeomagnetic measurements were performed on U-channel samples from the three cores at 1$\mathrm{cm}$ intervals using a $2 \mathrm{G}$ Enterprises ${ }^{\mathrm{TM}}$ SRM-755 cryogenic magnetometer and a pulse magnetizer (for the induction of isothermal remanent magnetizations (IRMs)). The data points from the upper and lower $4 \mathrm{~cm}$ of each U-channel were not used in order to eliminate edge effects due to the response function of the magnetometer's pick-up coils (Weeks et al. 1993). The natural remanent magnetization (NRM) was measured and followed by alternating field (AF) demagnetization at peak fields of 0 to $80 \mathrm{mT}$ (5-mT increments) to determine the characteristic remanent magnetization (ChRM). Subsequently, a continuous field of $50 \mu \mathrm{T}$ (direct current (DC) bias field) was applied to the sample at the same time as a $100 \mathrm{mT}$ alternating field in order to impart an anhysteretic remanent magnetization (ARM), followed by demagnetization steps at peak AF fields of 0 
to $70 \mathrm{mT}$ (5-mT increments). Finally, two IRMs were induced by applying a DC pulse field of $300 \mathrm{mT}$ (IRM) and $950 \mathrm{mT}$ (corresponding to a saturated isothermal remanent magnetization (SIRM)) and the IRM progressively demagnetized following the same procedure used for ARM. SIRM was demagnetized at peak fields of 0 , 10,30 and $50 \mathrm{mT}$.

The last three remanent magnetizations measured (ARM, IRMs) were acquired with the aim of characterizing changes in magnetic mineral concentration and magnetic grain size. The ARM was expressed as susceptibility of ARM ( $\left.\mathrm{k}_{\mathrm{ARM}}\right)$ by normalizing the ARM to the biasing field, and used to calculate the $\mathrm{k}_{\mathrm{ARM}} / \mathrm{k}_{\mathrm{LF}}$ ratio to characterize change in magnetic grain sizes (Maher \& Thompson 1999). Furthermore, a coercivity-dependent proxy was constructed by dividing the IRM at $0.3 \mathrm{~T}$ by the SIRM at $0.95 \mathrm{~T}$. Values of this ratio (pseudo S-ratio) close to 1 indicate low coercivity minerals such as magnetite (ferrimagnetic mineralogy), whereas lower values indicate the presence of high coercivity minerals such as hematite (e.g. St-Onge et al. 2003; Stoner \& StOnge 2007).

Using the Excel macro developed by Mazaud (2005), the magnetic declination and inclination were computed by principal component analysis (Kirschvink 1980) at 1$\mathrm{cm}$ intervals. This computation also provided the maximum angular deviation (MAD) values and the median destructive field (MDF). The MAD values provide a quantitative measurement of the analytical uncertainty and can provide an estimation of the quality of the palaeomagnetic data with values below $5^{\circ}$ indicating high-quality directional data (Stoner \& St-Onge 2007). These low MAD values are required for reliable PSV and relative palaeointensity (RPI) studies. The MDF is the value of the peak AF necessary to reduce the magnetic remanence to half of its initial value and reflects the mean coercivity state of the sample. Characteristic inclinations (ChRM I) and declinations (ChRM D) were determined using the AF demagnetization data from 10 to $50 \mathrm{mT}$. Inclination values should vary around the theoretical inclination of the geocentric axial dipole $\left(\mathrm{I}_{\mathrm{GAD}}\right)$ calculated as a function of the site latitude (Opdyke \& Henry 1969; Stoner \& St-Onge 2007). It was not possible to orientate sections during coring. Thus, declination data are relative and were corrected by rotating the data at section breaks with similar circular values (e.g. 0 and $360^{\circ}$ ) to obtain a continuous record. The determination of the RPI proxy from sediments was obtained by normalizing the measured NRM by an appropriate magnetic parameter (e.g. Tauxe 1993; Stoner \& St-Onge 2007) and the choice of the normalizer will be explained more extensively in the Results section.

\section{Chronology}

The age model of core Kane2B located in the Kane basin (Nares Strait) was established by Georgiadis et al. (sub- mitted). The model is based on 20 radiocarbon ages from mixed benthic foraminifera samples and mollusc shell fragments and combined with ${ }^{210} \mathrm{~Pb}$ dating for the core top. The relatively good preservation of the biogenic carbonates in this shallow $(220 \mathrm{~m})$ core allows the dating of such a large number of samples. This age model was constructed assuming a regional reservoir correction of $\Delta \mathrm{R}=240$ years (average $\Delta \mathrm{R}$ of three pre-bomb mollusc shells collected in Nares Strait, McNeely et al. 2006), and considering a relatively instantaneous $20-\mathrm{cm}$-thick clastrich deposit from 300 to $320 \mathrm{~cm}$ (Fig. 2 Georgiadis et al. submitted). According to this age model, core Kane2B covers the last $9.1 \mathrm{cal}$. ka BP.

Four and three AMS ${ }^{14} \mathrm{C}$ ages were measured on mixed benthic and planktonic foraminifer samples from cores 204 and 210, respectively (Table 2; Beta Analytic Inc. and LMC14). The conventional ${ }^{14} \mathrm{C}$ ages were calibrated using the CALIB 7.1 software (Stuiver et al. 2017; http://calib. org/calib/) and the Marine13 data set (Reimer et al. 2013). A regional reservoir age correction of $\Delta \mathrm{R}=140 \pm 30$ years was applied as estimated by Lloyd et al. (2011) and used in most recent palaeoceanographic studies in this area (e.g. Jennings et al. 2014; Moroset al. 2016; Jackson et al. 2017). Preliminary age models were computed for cores 204 and 210 using the CLAM 2.2 software (Blaauw 2010) and are shown in Fig. 2. CT-scan and lithological analyses revealed a major change of depositional environments in the lower part of core 210 (400 to $580 \mathrm{~cm}$ from the core top) where no radiocarbon ages are available. Thus, we decided to refrain from proposing any age model for this interval. In this study, these initial radiocarbon-based age/depth models served as a basis for the palaeomagnetic approach (correlation with chronostratigraphical markers) in order to improve the chronologies of cores 204 and 210. According to the preliminary age models, core 204 spans the last 9.2 cal. ka BP while core 210 covers at least the last $\sim 9.0$ cal. ka BP (Fig. 2). The age models of the three cores indicate sedimentation rates ranging from 10 to up to $200 \mathrm{~cm} \mathrm{ka}^{-1}$, in agreement with previous values found in the same geographical settings (e.g. Levac et al. 2001; Knudsen et al. 2008; Jennings et al. 2014; St-Onge \& St-Onge 2014).

\section{Results}

\section{Lithology}

The sediment characteristics of cores Kane2B, 204 and 210 are described below on the basis of CAT-scan images, sediment grain size, and their physical and magnetic properties.

Core Kane2 B. - Georgiadis et al. (submitted) proposed a postglacial palaeoenvironmental history of the central sector of Nares Strait and described extensively the stratigraphy of core Kane2B. Here, we only present a brief overview of new physical and magnetic data 
Table 1. Location of the sampling sites, water depth and length of the cores used in this study.

\begin{tabular}{|c|c|c|c|c|c|}
\hline Station & Latitude $\left({ }^{\circ} \mathrm{N}\right)$ & Longitude $\left({ }^{\circ} \mathrm{W}\right)$ & Region & Water depth (m) & Core length $(\mathrm{cm})$ \\
\hline AMD14-204 & $73^{\circ} 15.663^{\prime}$ & $57^{\circ} 53.987^{\prime}$ & Upernavik Isstrøm & 987 & 734 \\
\hline AMD14-210 & $75^{\circ} 24.317^{\prime}$ & $61^{\circ} 39.357^{\prime}$ & Melville Bay & 1155 & 596 \\
\hline AMD14-Kane 2B & $79^{\circ} 30.908^{\prime}$ & $70^{\circ} 49.742^{\prime}$ & Kane Basin & 220 & 425 \\
\hline
\end{tabular}

obtained to complete their description (Fig. 3A). We also observed three major lithological units along the core. Unit 1 (from the base, 427 to $394 \mathrm{~cm}$ ) is composed of greyish brown (Munsell colour 10YR 5/2) sandy mud with dropstones (matrix-supported diamicton) and is associated with unit A from Georgiadis et al. (submitted). This unit is characterized by high CT number values, low $\mathrm{a}^{*}$ values and low magnetic susceptibility values $\left(\mathrm{k}_{\mathrm{LF}}\right)$. A gradual change of colour occurs above $394 \mathrm{~cm}$, corresponding to the boundary with unit 2. Unit 2 (394 to $275 \mathrm{~cm}$ ) is mostly composed of clayey silts and can be divided into three subunits, associated to units B, C and D from Georgiadis et al. (submitted). Subunit 2a (from 394 to $320 \mathrm{~cm}$ ) is a stratified greyish brown clayey silts unit with pebbles and is characterized by low wet bulk density and high $\mathrm{a}^{*}$ (red) values. Traces of bioturbation are also observed in subunit $2 \mathrm{a}$. Subunit $2 \mathrm{~b}(320$ to $300 \mathrm{~cm})$ is a rapidly deposited layer (St-Onge et al. 2012) characterized by a sharp change of colour (dark to very dark greyish brown, $2.5 \mathrm{Y} 4 / 2$ to $3 / 2$ ) and composed of coarse sandy muds with dropstones. Subunit 2c $(300$ to $275 \mathrm{~cm}$ ) is a greyish brown clayey silt layer very similar to subunit $2 \mathrm{a}$. A sharp increase in the wet bulk density values marks the transition between units 2 and 3 . Unit 3 (275 $\mathrm{cm}$ to the top), associated with unit E from Georgiadis et al. (submitted), is characterized by a decrease in clay and sand content ( $>80 \%$ silts) and is composed of dark greyish brown $(2.5 \mathrm{Y}$ 4/2) bioturbated silts with pebbles and broken shells characterized by higher density and lower a* values. The first part of unit 3 (subunit 3a, 275 to $200 \mathrm{~cm}$ ) contains traces of bioturbation and is rich in pebbles, whereas subunit $3 \mathrm{~b}(200 \mathrm{~cm}$ to the top) is strongly bioturbated and broken shells are present.
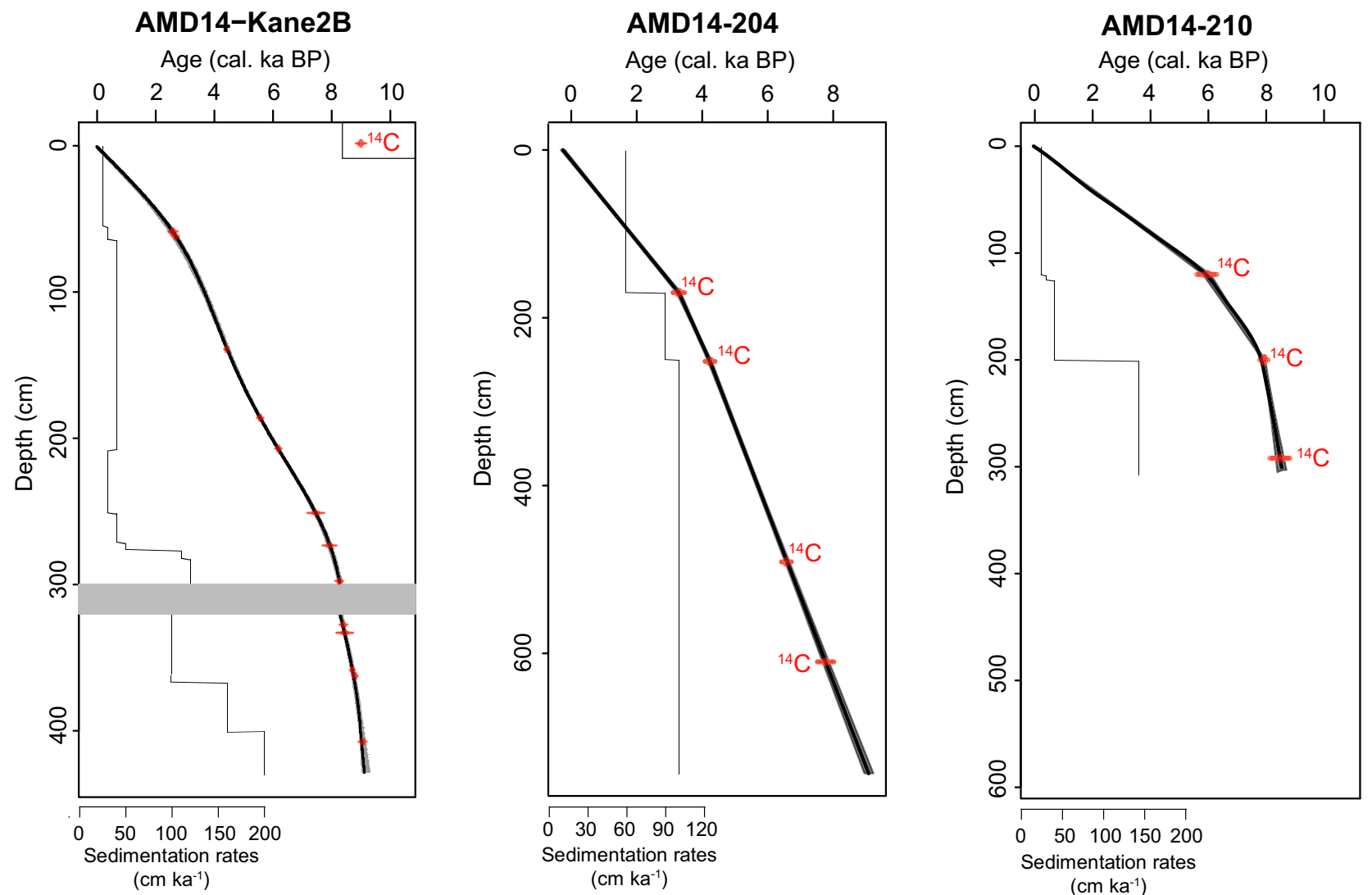

Fig. 2. Radiocarbon-based age models of cores AMD14-Kane2B, AMD14-210 and AMD14-204. Age reservoir correction based on McNeely et al. (2006) for core Kane2B $(\Delta=240$; Georgiadis et al. submitted) and Lloyd et al. (2011) for cores 204 and $210(\Delta=140 \pm 30)$. Estimated sedimentation rates in $\mathrm{cm} \mathrm{ka}^{-1}$ are indicated. 
Table 2. Radiocarbon ages for cores AMD14-204 and AMD14-210. The ages were calibrated using the CALIB version 7.1 software (Stuiver et al. 2017) and the Marine13 calibration curve (Reimer et al. 2013) (1 $; ; 95.4 \%$ area enclosed). Age reservoir corrections applied based on McNeely et al. (2006) for core Kane2B ( $\Delta=240$; Georgiadis et al. submitted) and on Lloyd et al. (2011) for cores 204 and $210(\Delta=140 \pm 30)$.

\begin{tabular}{llllllll}
\hline Core & Depth $(\mathrm{cm})$ & $\begin{array}{l}\text { Laboratory } \\
\text { number }\end{array}$ & Dated material & $\begin{array}{l}{ }^{14} \text { C age } \\
(\mathrm{a} B P)\end{array}$ & $\begin{array}{l}\text { Error } \\
( \pm \mathrm{a} \text { BP })\end{array}$ & $\begin{array}{l}\text { Age ranges } \\
(\mathrm{cal} \text { a BP })\end{array}$ & $\begin{array}{l}\text { Median age } \\
(\mathrm{cal} . \mathrm{a} \text { BP })\end{array}$ \\
\hline AMD14-204 & $169-170$ & SacA46004 & Mixed benthic and planktonic foraminifera & 3555 & 35 & $3155-3397$ & 3280 \\
AMD14-204 & $251-253$ & BETA467785 & Mixed benthic and planktonic foraminifera & 4300 & 30 & $4098-4379$ & 4240 \\
AMD14-204 & $500-503$ & BETA488641 & Mixed benthic foraminifera & 6400 & 30 & $6652-6768$ & 6711 \\
AMD14-204 & $609-611$ & SacA46005 & $\begin{array}{l}\text { Mixed benthic and planktonic } \\
\text { foraminifera and ostracods }\end{array}$ & 7445 & 50 & $7650-7907$ & 7770 \\
AMD14-210 & $119-121$ & GIFA17340 & Mixed benthic and planktonic foraminifera & 5530 & 70 & $5594-5908$ & 5760 \\
AMD14-210 & $200-201$ & BETA463137 & Mixed benthic and planktonic foraminifera & 7440 & 30 & $7658-7865$ & 7760 \\
AMD14-210 & $291-292$ & GIFA17339 & Mixed benthic and planktonic foraminifera & 7990 & 70 & $8152-8469$ & 8310 \\
\hline
\end{tabular}

Core 210. - Significant changes in the physical and magnetic parameters reveal a variable lithology throughout core 210, which allowed the identification of three distinct units presented in Fig. 3B. Unit 1 (577 to $388 \mathrm{~cm}$ ) is composed of greyish brown (5Y 5/2) clayey silts with numerous pebbles and coarse material (matrixsupported diamicton) reflected by high magnetic susceptibility and CT number values. The top of unit 1 (from 410 to $388 \mathrm{~cm}$ ) is marked by sedimentary structures (oblique to planar laminations) that indicate a progressive change of environment and mark the transition between unit 1 and unit 2. Unit 2 (388 to $182 \mathrm{~cm}$ ) can be divided into two subunits. Subunit $2 \mathrm{a}$ (388 to $320 \mathrm{~cm}$ ) is a massive greyish brown (5Y 5/2) clayey silt unit with no major sedimentary structures, except very subtle laminations, and has the highest clay content $(>35 \%)$ compared to other units. It is characterized by low wet bulk density and $\mathrm{k}_{\mathrm{LF}}$ values. This subunit is probably associated to the deposition of suspended sediments, possibly from turbid meltwater plumes. A gradational contact separates subunit $2 \mathrm{a}$ from subunit $2 \mathrm{~b}(320$ to $182 \mathrm{~cm})$, marked by traces of bioturbation, which contrast with the homogeneous subunit 2a. Subunit $2 \mathrm{~b}$ is a stratified greyish brown $(5 \mathrm{Y} 5 / 2)$ silt unit with an alternation of fine and coarse layers. Coarse layers (up to $\sim 10 \mathrm{~cm}$ thick) are characterized by a higher coarse silt content and by their erosive bases. Overall, two very coarse grain-size peaks around 190-194 cm and 390-395 cm are also observed in the CT-scans and are associated with high wet bulk density and high magnetic susceptibility (grey shading, Fig. 3B). Finally, unit 3 (from $182 \mathrm{~cm}$ to the top) is a strongly bioturbated greyish brown silt unit with low numbers of $>2$ mm clasts.

Core 204. - Core 204 is mainly composed of a homogeneous hemipelagic sedimentary facies and is divided into two units (Fig. 3C). The matrix-supported diamicton observed in cores Kane-2B and 210 is not observed in this core. However, units 1 and 2 were distinguished based on the physical and magnetic properties. Unit 1 (737 to $610 \mathrm{~cm})$ is characterized by greyish brown $(2.5 \mathrm{Y} 4 / 2)$ homogeneous clayey silts with high a* (red), magnetic susceptibility and wet bulk density values and the lowest coarse silt content throughout the core. Unit $2(610 \mathrm{~cm}$ to the top) is composed of homogeneous clayey silts and can be divided into two subunits. Subunit 2a (610 to $190 \mathrm{~cm}$ ) is characterized by bioturbated olive grey (5Y 4/2) clayey silts and a slightly increasing grain size. Subunit $2 \mathrm{~b}$ $(190 \mathrm{~cm}$ to the top) is also composed of strongly bioturbated olive grey ( $5 \mathrm{Y} 4 / 2)$ clayey silts, but is associated with a decrease in magnetic susceptibility and slightly higher $\mathrm{a}^{*}$ values in the uppermost $100 \mathrm{~cm}$.

\section{Magnetic properties}

Magnetic mineralogy. - The coercivity of a sample reflects its mean magnetic grain size and mineralogy. For the three cores, the shape of the hysteresis curves (Fig. 4A) is characteristic of low coercivity ferrimagnetic minerals such as magnetite, and the saturation fields are below $0.2 \mathrm{~T}$, which are indications of the presence of magnetite (Tauxe et al. 1996). Moreover, the Day plot (Fig. 4B) displays most of the Mrs/Ms values ranging between 0.1 and 0.3 , which is typical of pseudo-single domain (PSD) magnetite or titanomagnetite grains (Day et al. 1977; Tauxe 1993; Dunlop 2002). The two slightly separated points of core 210 , outside the theoretical lines for PSD or multi-domain (MD) grains, are from the two coarse layers at $\sim 192$ and $\sim 392 \mathrm{~cm}$. The Pseudo-S-ratio varies between $\sim 0.8$ and 1 (Fig. 3), and the mean values are $0.99 \pm 0.02$ for core Kane2B, $0.9 \pm 0.03$ for core 210 and $0.92 \pm 0.04$ for core 204. Values $>0.9$ indicate that much of the saturation of the magnetic assemblage is achieved in a $0.3 \mathrm{~T}$ field, which is typical of low coercivity and ferrimagnetic minerals, such as magnetite and/or titanomagnetite (Stoner \& St-Onge 2007), while values lower than 0.8 indicate the possible presence of higher coercivity minerals such as goethite or hematite (Frank \& Nowaczyk 2008). Furthermore, for the basal (base to $600 \mathrm{~cm}$ ) and uppermost (190 $\mathrm{cm}$ to top) parts of core 204 , high $\mathrm{a}^{*}$ (red) and high $\mathrm{MDF}_{\mathrm{NRM}}$ values are suggestive of the presence of hematite. However, $\mathrm{MDF}_{\mathrm{NRM}}$ 


\section{A AMD14 - Kane2B}

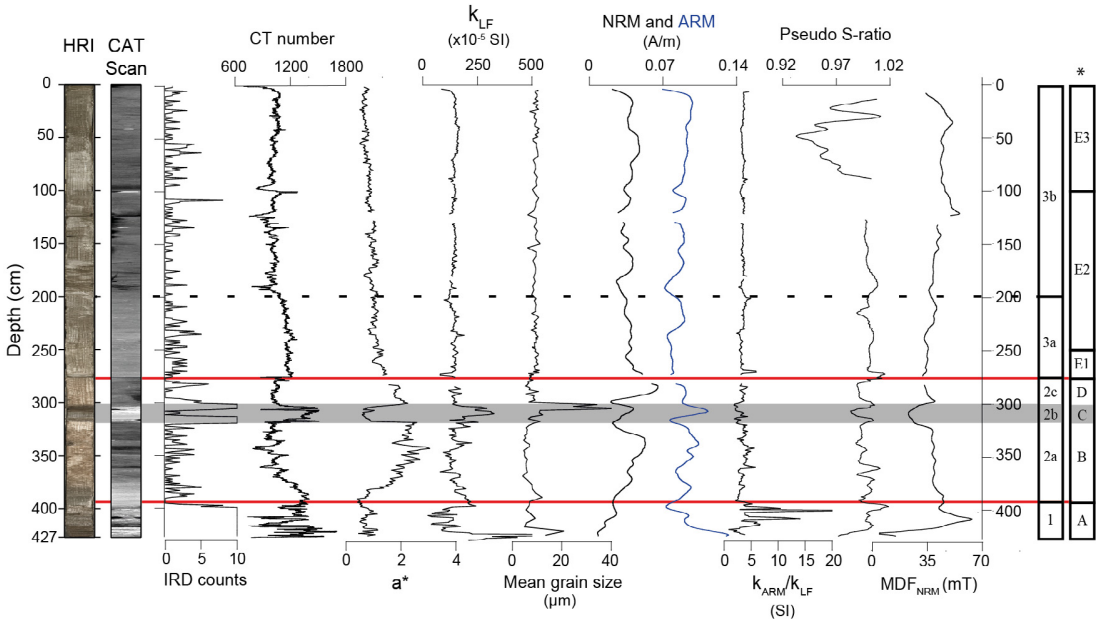

B AMD14 - 210

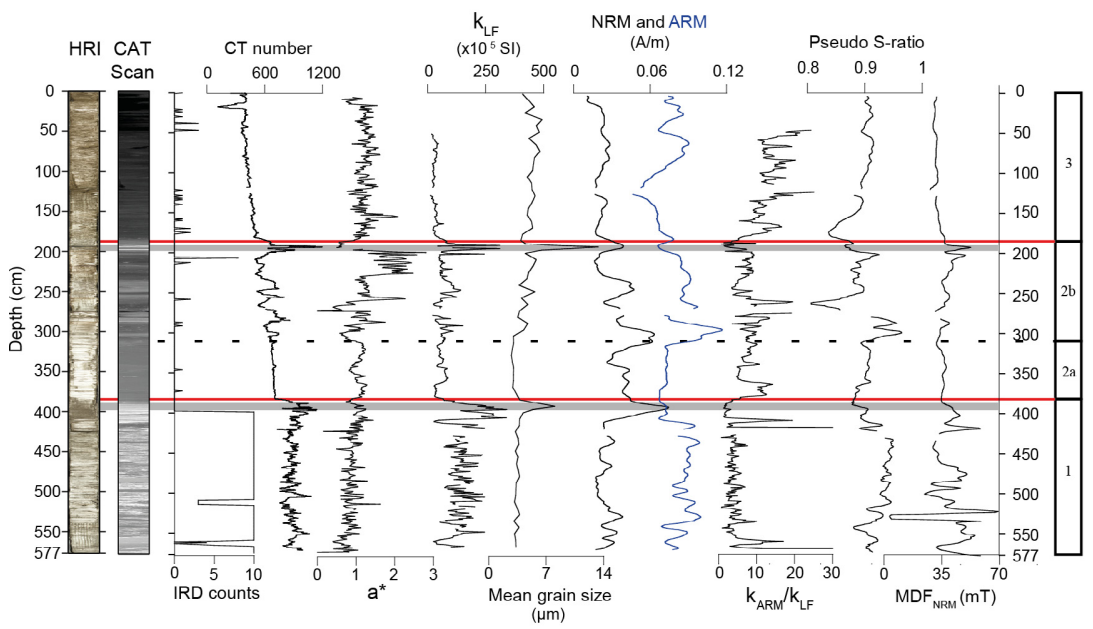

C AMD14 - 204

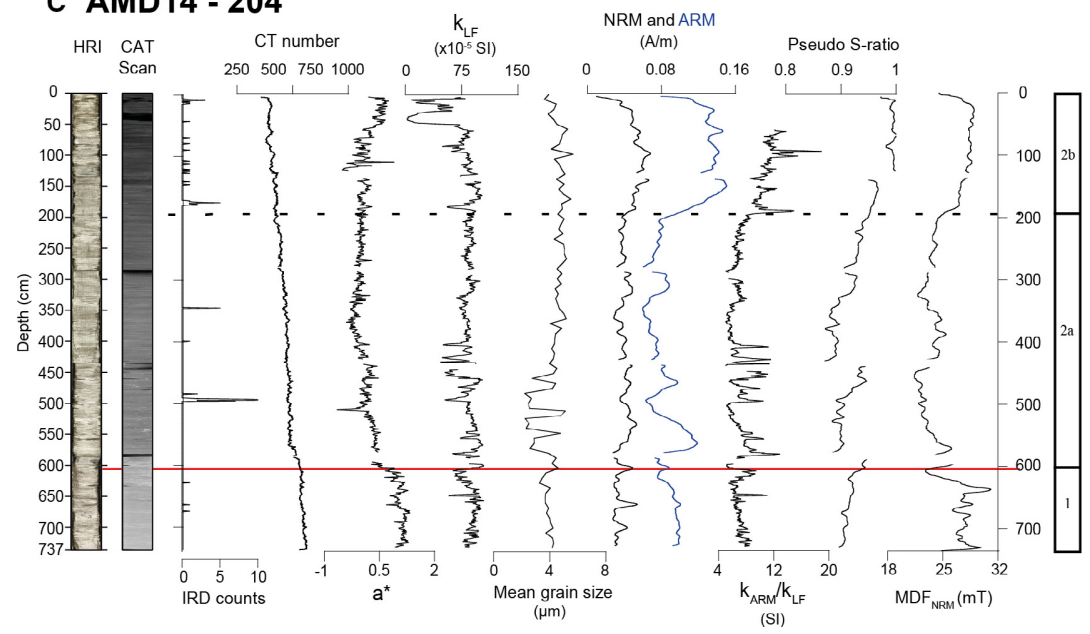

Fig. 3. High-resolution down-core physical and magnetic properties for cores Kane2B (A), 210 (B) and 204 (C). HRI = high-resolution digital image; $\mathrm{CT}=\mathrm{CAT}$-scan image of the core; IRD counts based on X-ray images (CT-scan); computerized tomography (CT) number (density proxy); $\mathrm{a}^{*}($ green to red $)=$ sediment colour; $\mathrm{k}_{\mathrm{LF}}=$ low-field volumetric magnetic susceptibility; Mean grain size $(\mu \mathrm{m})$; mean of natural and anhysteretic remanent magnetization (respectively NRM and ARM) calculated for the demagnetization range $10-50 \mathrm{mT} ; \mathrm{k}_{\mathrm{ARM}} / \mathrm{k}_{\mathrm{LF}}$ ratio $=$ magnetic grain-size indicator; pseudo S-ratio $\left(\mathrm{IRM}_{0 \mathrm{mT}} / \mathrm{SIRM}_{0 \mathrm{mT}}\right)=$ magnetic mineralogy indicator; $\mathrm{MDF}_{\mathrm{NRM}}(\mathrm{mT})=$ magnetic mineralogy indicator. Distinct lithological facies are delimited by solid red and dotted black lines. Rapidly deposited layers are highlighted in grey. The different units delimited by Georgiadis et al. (submitted) for core Kane2B are also shown. 
A

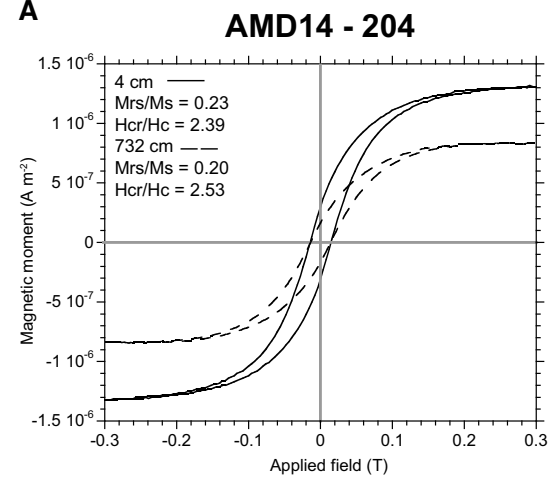

AMD14 - 210

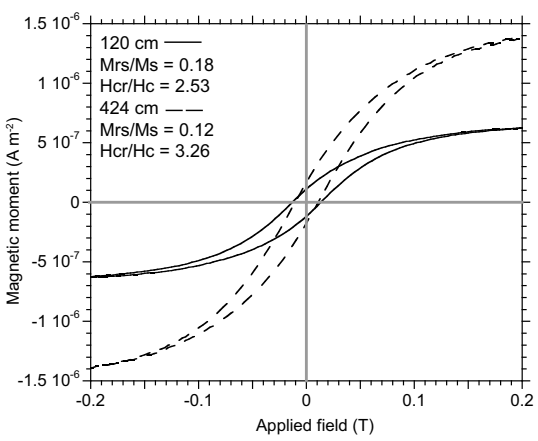

AMD14 - Kane2B

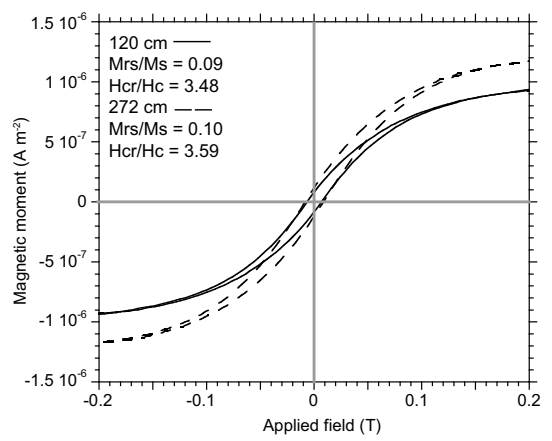

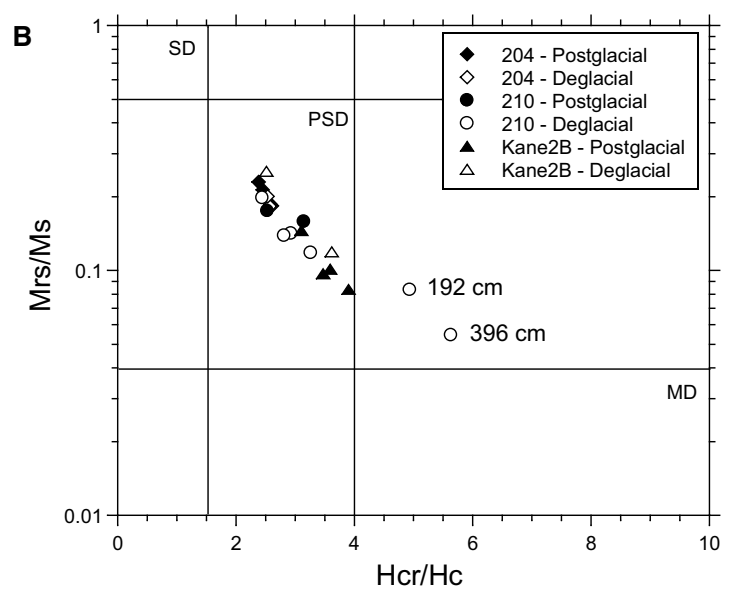

C

AMD14 - 204

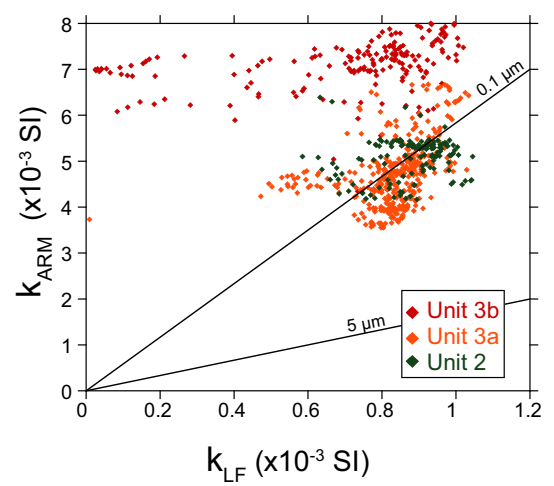

AMD14 - 210

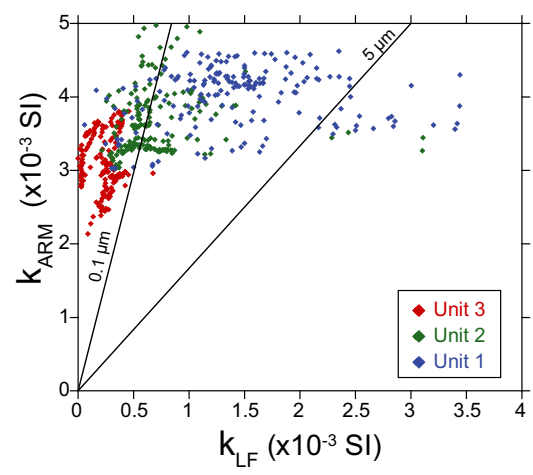

AMD14 - Kane2B

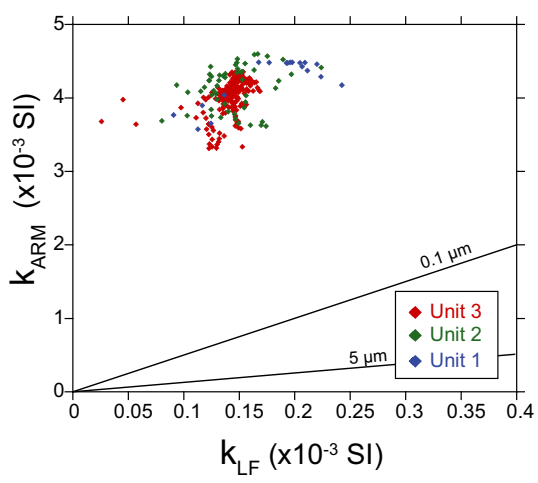

Fig. 4. Magnetic mineralogy. A. Representative hysteresis loops for the three cores 204, 210 and Kane2B. B. Day plot (Day et al. 1977) of selected samples. The horizontal and vertical lines delimitate the theoretical area for single domain (SD), pseudo-single domain (PSD) and multi-domain (MD) magnetite grains. C. $\mathrm{k}_{\mathrm{ARM}}$ Vs. $\mathrm{k}_{\mathrm{LF}}$ biplot for estimation of magnetic grain size for magnetite based on King et al. (1983).

values of $25-30 \mathrm{mT}$ for core 204 also indicate the presence of low coercivity minerals (Dankers 1981). $\mathrm{MDF}_{\mathrm{NRM}}$ values for cores 210 and Kane2B vary between $30-50$ and $35-45 \mathrm{mT}$, respectively, indicating slightly higher coercivities than in 204 (Fig. 3). These results, together with the hysteresis loops, point to generally low coercivity minerals, such as magnetite, as being the dominant remanence carriers throughout most of the three cores, although higher coercivity minerals (e.g. hematite) may be present within specific depth-intervals as discussed above.

Magnetic grain size and concentration. - According to the Day plot (Fig. 4B), the data indicate that the magnetic grains are in the PSD range, with the exception of the two samples from the coarse layers in core 210. Furthermore, the magnetic grain-size sensitive ratio $\mathrm{k}_{\mathrm{ARM}} / \mathrm{k}_{\mathrm{LF}}$ suggests a finer magnetic grain size towards the top of cores 210 and 
204 (higher values in units 3 and 3b, respectively), whereas lower values of $\mathrm{k}_{\mathrm{ARM}} / \mathrm{k}_{\mathrm{LF}}$ suggest a coarser magnetic grain size for unit 1 of 210 and units 2 and 3a of 204 (Fig. 3). Values of $\mathrm{k}_{\mathrm{ARM}} / \mathrm{k}_{\mathrm{LF}}$ in core Kane $2 \mathrm{~B}$ are generally lower than the two other cores, indicating a coarser magnetic grain size. Moreover, $\mathrm{k}_{\mathrm{ARM}}$ vs. $\mathrm{k}_{\mathrm{LF}}$ biplots (Fig. 4C) reveals a relatively fine magnetic grain size $(<5 \mu \mathrm{m})$. The underlying data must be used with caution because the absolute values were based on synthetic magnetic grains, although they indicate an optimal size range (Tauxe 1993) for relative palaeointensity determination. In addition, an ideal sequence for relative palaeointensity determinations should have a relatively uniform concentration of magnetic grains, within one order of magnitude. Thus, in the three sedimentary records, the remanent magnetization curves (NRM, ARM, Fig. 3 and IRM, not shown) indicate concentration variations below than a factor of 10 , which is satisfactory for palaeointensity reconstructions (e.g. Tauxe 1993; Valet \& Meynadier 1998; Stoner \& St-Onge 2007).

\section{Palaeomagnetic directional data}

The vector end-point diagrams (Fig. 5B) reveal a strong and stable ChRM after removal of a viscous magnetization at AF $10 \mathrm{mT}$ demagnetization step. In addition, for most of the three records, the ChRM inclinations vary around the GAD, indicating a coherent directional signal (Fig. 5A). Nevertheless, some intervals in cores Kane2B and 210 (mainly coarse layers, turbidites, or a magnetic mineral assemblage not suitable for recording the geomagnetic field, for example IRD-rich layers) do not adhere to the GAD. These intervals are less reliable for PSV and RPI reconstructions and will be considered with caution. Similarly, core section edges are also highlighted in grey and excluded from the reconstructions (highlighted intervals in Figs 5A and 7).

\section{Relative palaeointensity (RPI) determination}

To assess the reliability of a RPI proxy, several criteria must be fulfilled (e.g. Levi \& Banerjee 1976; Tauxe 1993; Stoner \& St-Onge 2007). As discussed previously, the magnetic parameters and hysteresis properties of the three cores point to a mostly well-defined, strong and stable characteristic magnetization carried by relatively low coercivity ferrimagnetic minerals such as magnetite in the PSD domain. The MAD values are below $5^{\circ}$ (Fig. 5A) and magnetic concentrations vary within one order of magnitude (Tauxe 1993; Valet \& Meynadier 1998). The construction of the proxy records of RPI from sediments requires a normalization of the NRM by an appropriate magnetic parameter in an attempt to eliminate the influence of changes in magnetic mineralogy, concentration, and grain size. Usually, ARM, IRM or $\mathrm{k}_{\mathrm{LF}}$ are chosen as the normalizer (e.g. King et al. 1983; Tauxe 1993; Stoner \& St-Onge 2007). However, because it is highly influenced by concentration and grain size, $\mathrm{k}_{\mathrm{LF}}$ was excluded here. The normalizer must have a similar coercivity spectrum as the NRM and should not be coherent with the RPI proxy. The average AF field interval (demagnetization steps) of 10 to $50 \mathrm{mT}$ was selected for the three cores (Fig. 6A) as they are part of the ChRM and each individual ratio is consistent over this interval.

Two different methods are available to determine the best normalizer: (i) the widely used average ratio method (e.g. Channell et al. 2000; Stoner et al. 2000) and (ii) the pseudo-Thellier method or 'slope method' (Tauxe et al. 1995; Channell et al. 2002; Snowball \& Sandgren 2004). The ratio method consists of averaging the normalized NRM at different demagnetization steps, whereas the slope method uses the best-fit slope of the NRM vs. the normalizer between two different demagnetization steps (Tauxe et al. 1995). The demagnetization curves (Fig. 6A) indicate that the grains acquiring the ARM better activate the same grains carrying the NRM than the IRM for cores Kane2B and 210, whereas it is similar between ARM and IRM for core 204. Finally, the normalizer should not be correlated with the RPI proxy or with any lithological proxy (Tauxe \& Wu 1990). For cores Kane2B and 210, no correlation with the normalizer is observed with $\mathrm{NRM}_{10}$ $50 \mathrm{mT} / \mathrm{ARM}_{10-50 \mathrm{mT}}\left(r^{2}=0.08\right.$ and 0.04 , respectively), whereas for core $204, \mathrm{NRM}_{10-50 \mathrm{mT}} / \mathrm{IRM}_{10-50 \mathrm{mT}}$ is the least coherent with its normalizer $\left(r^{2}=0.004\right)$ (Fig. 6C). Based on these results, we selected $\mathrm{ARM}_{10-50 \mathrm{mT}}$ as the best normalizer for cores Kane2B and 210 and IRM $\mathrm{ID}_{10-50 \mathrm{mT}}$ for core 204.

\section{Discussion}

\section{Reliability considerations}

Tauxe (1993) demonstrated that the palaeomagnetic signal derived from sedimentary archives should be validated by an extensive analysis of the magnetic characteristics in order to verify the reliability of the palaeomagnetic signal recorded. In our study, we have demonstrated that except for two coarser layers, the magnetic grain sizes of the three cores are in the PSD range and are thus in the ideal magnetic grain-size window for palaeointensity determination. Moreover, magnetite is the dominant remanence carrier of a welldefined and strong ChRM with a uniform concentration of magnetic grains and the MAD values are below $5^{\circ}$. Thus, the results presented above confirmed that the three cores (Kane2B, 210 and 204) satisfy the criteria for the determination of PSV and RPI records (e.g. King et al. 1983; Tauxe 1993; Stoner \& St-Onge 2007).

\section{Palaeomagnetic dating and age modelling}

The full palaeomagnetic vectors (inclination, declination, and relative palaeointensity) were first constructed using the initial radiocarbon-based age model of each core(Fig. 2) and then cross-compared (Fig. 7) in order to 
A AMD14 - Kane2B
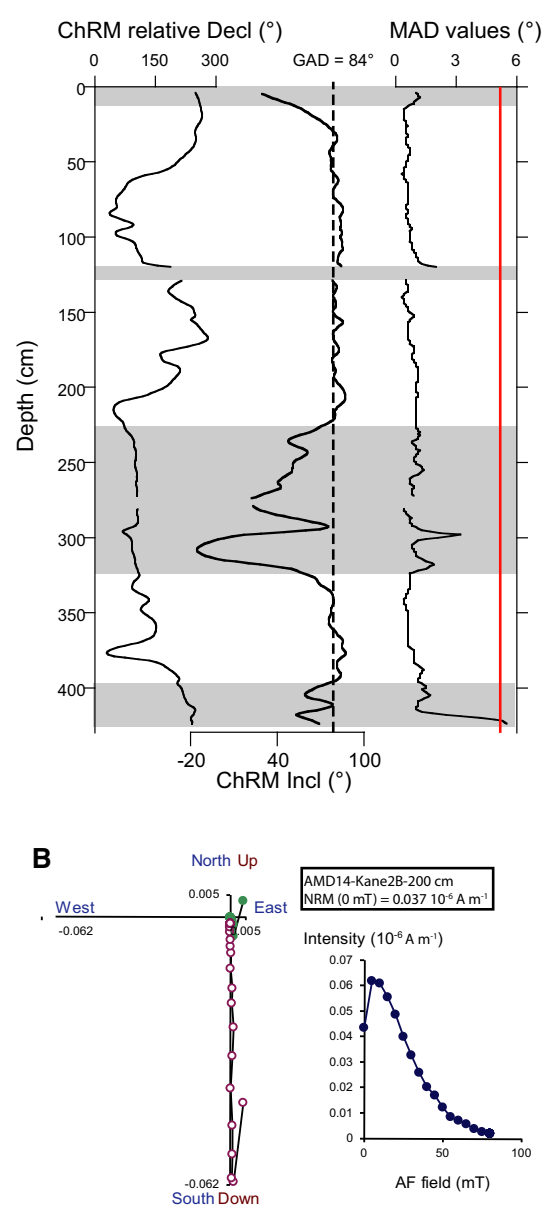

AMD14 - 210
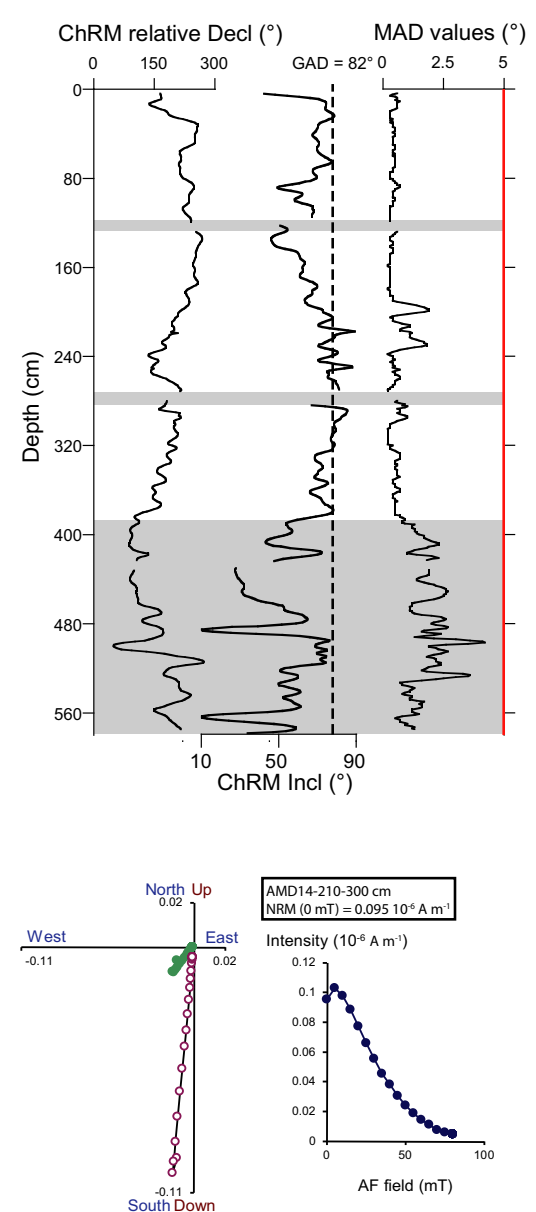

AMD14 - 204
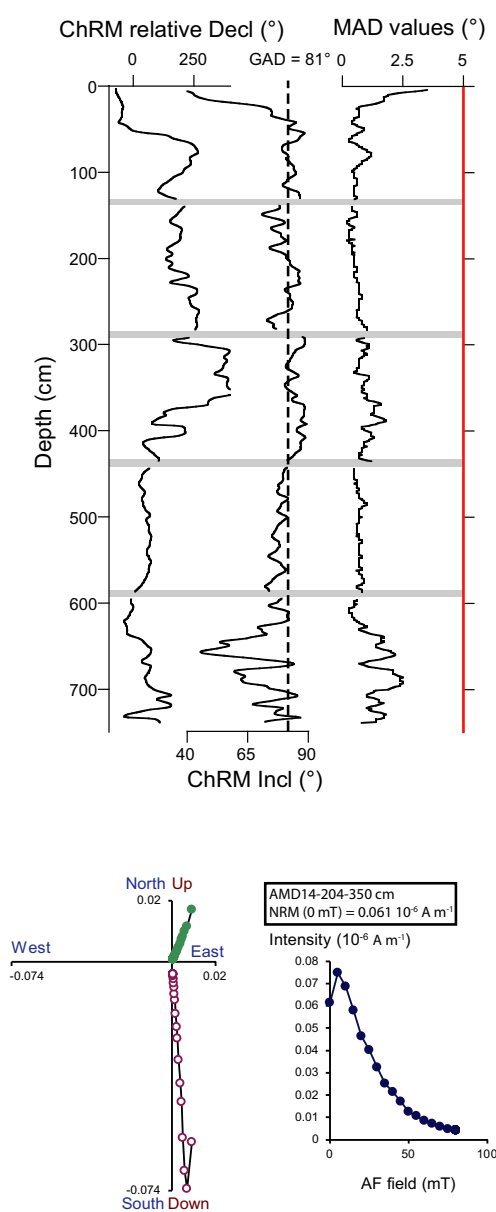

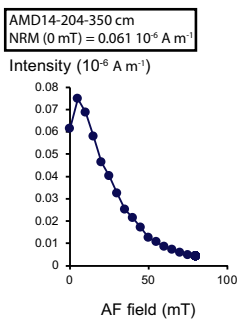

Fig. 5. A. Down-core variation of the ChRM declination, ChRM inclination and MAD values for cores Kane2B, 210 and 204. The vertical line on the inclination graphs indicates the expected GAD value for the latitude of the sampling sites. Unreliable intervals for palaeomagnetic reconstruction are highlighted in grey. B. AF demagnetization behaviour and orthogonal projection diagrams (Zijderveld 1967) of samples selected from the three cores.

constrain the chronology of cores 204 and 210. To improve the identification of similar directional and relative palaeointensity features, the three cores were also compared to other regional palaeomagnetic records (Fig. 7; Greenland-Iceland PSV composite and Site U1305 RPI from Stoner et al. 2013; Eastern Canadian Palaeostack from Barletta et al. 2010; HU2008-42 from St-Onge \& St-Onge 2014 and St-Onge 2012) and the geomagnetic field model (CALS10k.1b, Korte et al. 2011) calculated for each of our locations. Our comparison revealed coherent changes in the Earth's magnetic field behaviour and allowed to determine chronostratigraphical markers (palaeomagnetic tie-points) between the different records. Overall, 18 chronostratigraphical markers were identified using inclination, declination, and relative palaeointensity (Fig. 7, Table 3), respectively named as I, D and P hereafter. The terms maxima and minima are used here to characterize, respectively, high or low features of the PSV sequences. These common features are five maxima (I1, I4, I5, I6 and I7, respectively, around 1500, 3450, 4600, 5925 and 8250 cal. a BP) and threeminima(I2, I3 and I8, respectively, around 1675, 2450 and 9000 cal. a BP) for the inclination; two maxima (D1 and D4, respectively, around 1950 and $8700 \mathrm{cal}$. a BP) and three minima (D2, D3 and D5, respectively, around 3600, 6250 and 9025 cal. a BP) for the declination; and finally, three maxima (P1, P2 and P3, respectively, around 2325, 3375 and 4900 cal. a BP) and two minima (P4 and P5, respectively, around 5450 and $7300 \mathrm{cal}$. a BP) for the RPI. The standard deviation age (temporal shifts observed between the individual records due to their intrinsic chronological uncertainties) was calculated with ages observed on the radiocarbon-based age models, giving a maximum value of 239 years (Table 3). Nonetheless, chronological differences are observed for some of the palaeomagnetic features, especially between our records and the geomagnetic field model (CALS10k.1b; Fig. 7). We suggest these differences with the model outputs are 
A
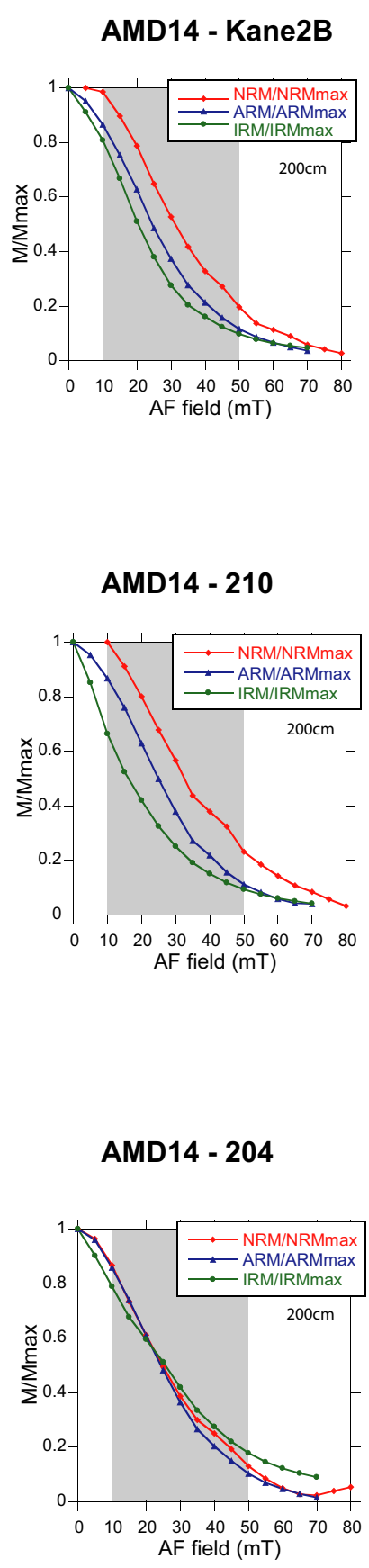
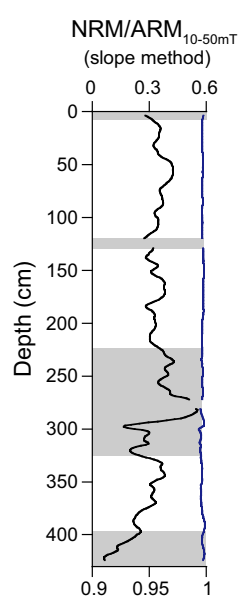

$R$

NRM/ARM
(slope method)

$\begin{array}{lll}0 & 0.4 & 0.8\end{array}$

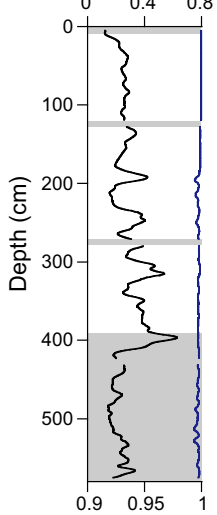

$\mathrm{R}$

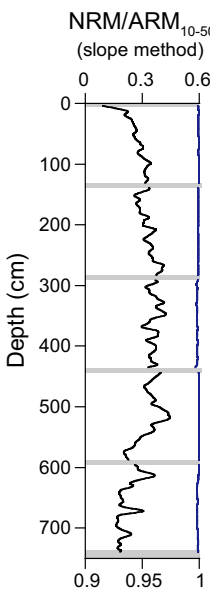

$\mathrm{R}$
B

$\mathrm{NRM} / \mathrm{IRM}_{10-50 \mathrm{mT}} \mathrm{NRM} / \mathrm{ARM}_{10-50 \mathrm{mT}} \mathrm{NRM} \mathrm{IRM}_{10-50 \mathrm{mT}}$

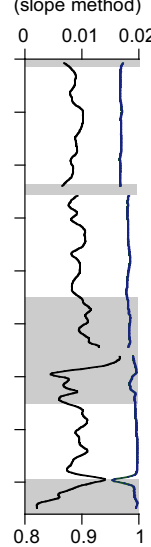

$\mathrm{R}$

NRM/IRM

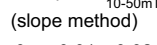

$\begin{array}{lll}0 & 0.01 & 0.02\end{array}$

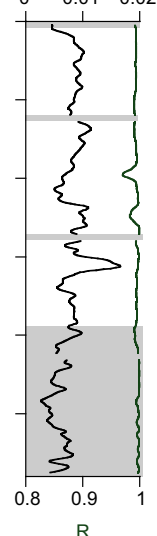

$\mathrm{R}$

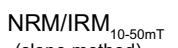

(slope method)
(10-50m

NRM/ARM ${ }_{10-50 \mathrm{mT}}$

(ratio method)

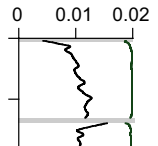

${ }_{3}^{0} 1^{0.3 \quad 0.6}$

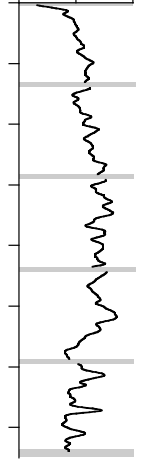

$\mathrm{NRM} / \mathrm{RRM}$

(ratio method)

$\begin{array}{lll}0 & 0.01 & 0.02\end{array}$

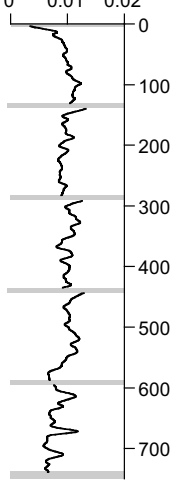

C
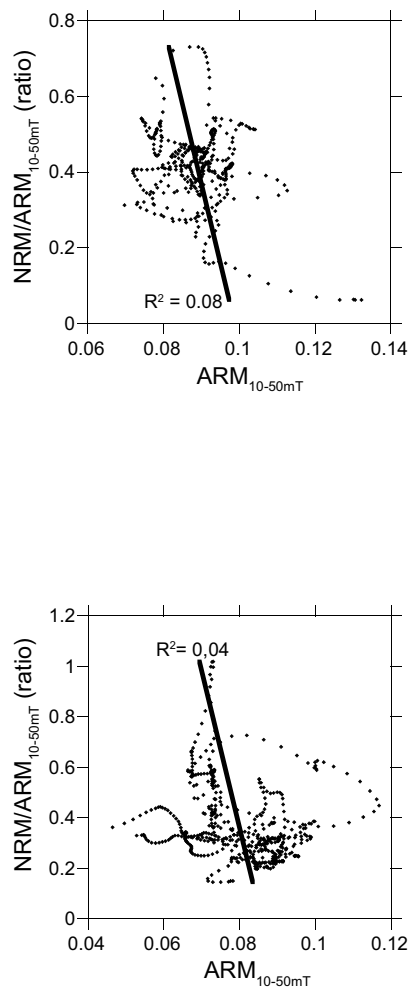

Fig. 6. Construction of the RPI proxy. A. Demagnetization curves for NRM, ARM and IRM. B. Comparison of the relative palaeointensity estimates based on the average ratios and the slope methods with the average ratios of NRM/ARM and NRM/IRM at 10-50 mT. C. RPI proxy vs. its normalizer with correlation coefficients.

related to differences in the chronologies and the lack of data from Baffin Bay (or the Eastern Arctic) for constraining the model(Korte et al. 2011). Differences between PSV records and geomagnetic field models were also observed in previous high-latitude studies (e.g. Snowball et al. 2007; Sagnotti et al. 2012; Walczak et al. 2017). We therefore 


\section{A Inclination}

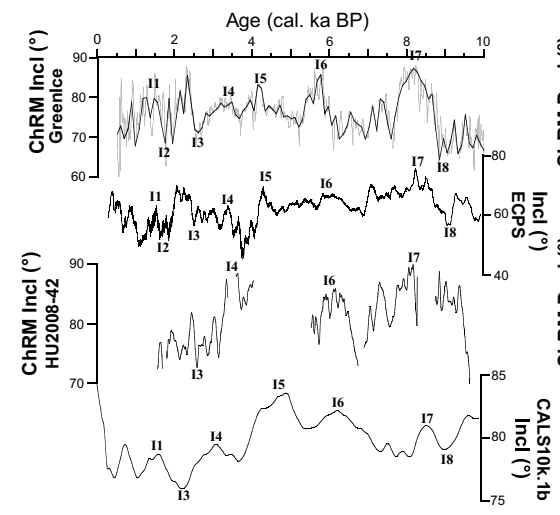

B Declination
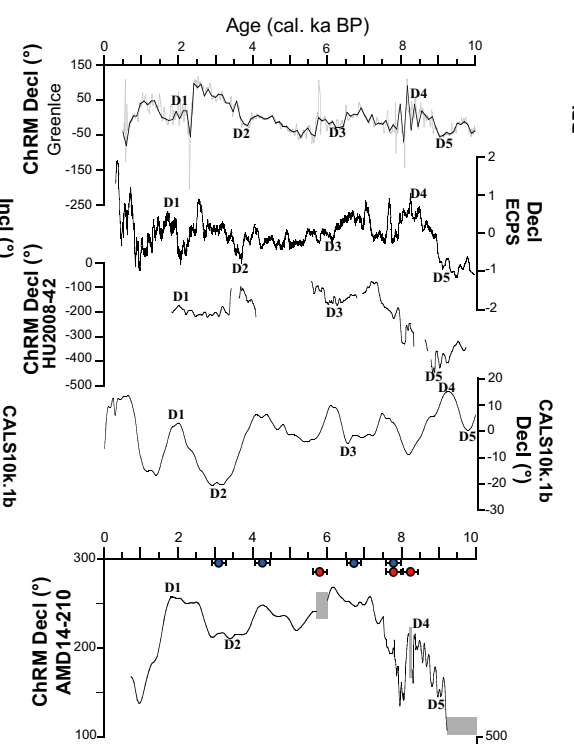
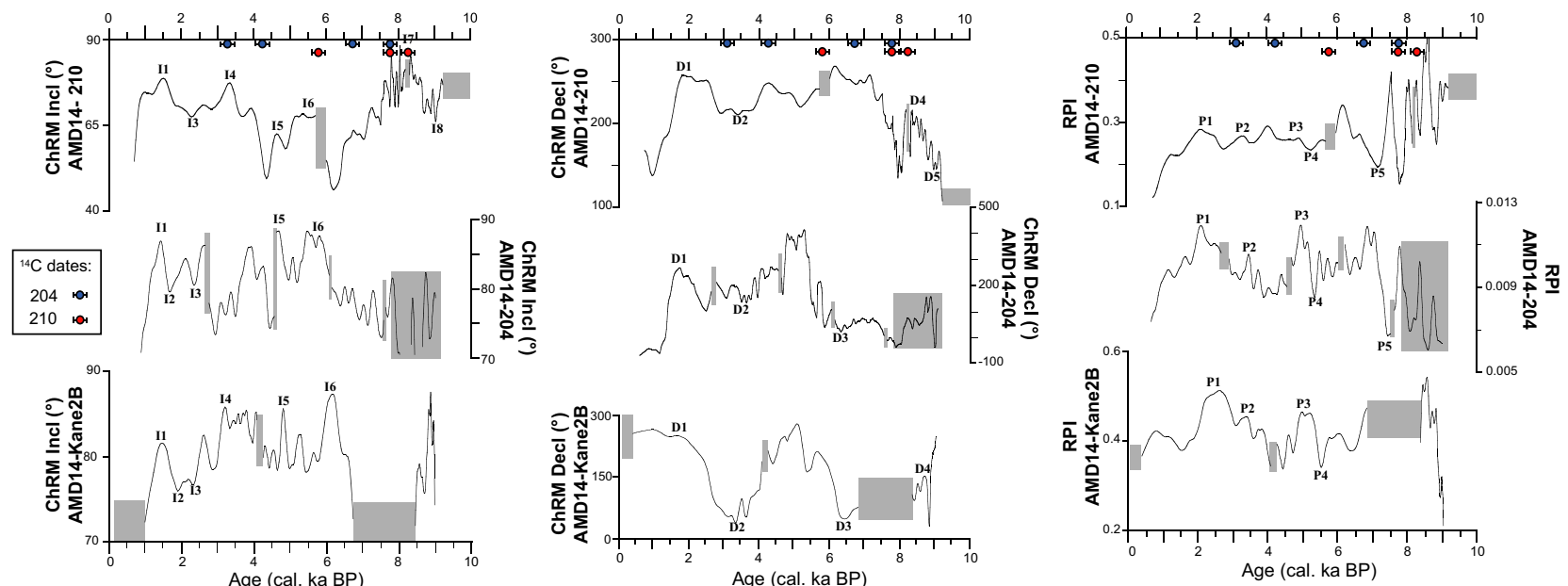

Fig. 7. Full vector palaeomagnetic comparison of (A) inclination, (B) declination and (C) relative palaeointensity between the three cores of this study (Kane2B, 210 and 204) compared to Green-Ice and Site U1305 records from Stoner et al. (2013), Eastern Canada Paleostack from Barletta et al. (2010), core HU2008-42 from St-Onge \& St-Onge (2014) and finally the CALS10k.1b geomagnetic field model from Korte et al. (2011). The unreliable intervals established in Fig. 5 (highlighted in grey) were not plotted in this figure. Red and blue circles correspond to the six radiocarbon ages used in this study for cores 210 and 204 , respectively.

choose to exclude the geomagnetic model outputs as chronostratigraphical markers and focus the comparison on independently radiocarbon-dated records (Table 3 ). As such, we illustrate the coherence between core 210, the most continuous sequence of the newly presented cores and the Greenland-Iceland PSV composite (Stoner et al. 2013) inclination records (Fig. 8A), as inclination is the dominant component of the palaeomagnetic vector at these high latitudes. The Greenland-Iceland PSV composite record is extremely well dated (combination of 44 radiocarbon ages from two cores, MD99-2269 and MD992322; Stoner et al. 2007) and the comparison clearly supports the validity of the chronostratigraphical markers. Moreover, the age offsets of the palaeomagnetic features with the Greenland-Iceland PSV composite (inclination and declination) are in the range of \pm 400 years (Fig. 8B), well within possible uncertainties associated with varying reservoir corrections, dating uncertainties, lock-in depth and/or local non-dipole field differences. Nevertheless, the inclination feature I5 has an offset between -350 to -500 years for our three records $(204,210$ and Kane2B) compared to the Greenland-Iceland composite record (Fig. 8B) andwas thus excluded as a chronostratigraphical marker.

The resulting chronostratigraphical markers (Fig. 7, Table 3) were then used to improve the initial radiocarbon-based age models of cores 204 and 210 . The AMS- ${ }^{14} \mathrm{C}$ dates and palaeomagnetic tie-points were combined using Clam (Blaauw 2010), which allowed the production of the age-depth models shown in Fig. 9. According to these proposed age models, the three cores cover the last 9.0/ 9.5 cal. ka BP and thus, most of the Holocene. A mean sedimentation rate of $85 \mathrm{~cm} \mathrm{ka}^{-1}\left(\sim 50\right.$ to $\left.110 \mathrm{~cm} \mathrm{ka}^{-1}\right)$ was assumed for core 204 from the Upernavik Isstrøm region. The age model for core 210 in Melville Bay suggests a lower sedimentation rate $\left(30\right.$ to $\left.40 \mathrm{~cm} \mathrm{ka}^{-1}\right)$ for the uppermost part of the core $(0-200 \mathrm{~cm})$ and an increased sedimentation rate $\left(\sim 130 \mathrm{~cm} \mathrm{ka}^{-1}\right)$ for the middle part of the core $(200-300 \mathrm{~cm})$, a pattern that is coherent with the lithological variations. This major change in sedimentation rate occurs around $\sim 7.5 \mathrm{cal}$. ka BP (Fig. 9). The chronology of the basal unit of core 210 
Table 3. Palaeomagnetic chronostratigraphical markers (tie-points) based on the correlation between the three cores (Kane2B, 210 and 204) presented in this study with three other palaeomagnetic records (Greenland-Iceland PSV composite and Site U1305, Stoner et al. 2013; Eastern Canada Paleostack, Barletta et al. 2010; HU2008-42PC, St-Onge \& St-Onge 2014) and the geomagnetic field model (CALS10k.1b, Korte et al. 2011) calculated for the localization of core 210 . Tie-points marked with I, D and P correspond respectively to inclination, declination and relative palaeointensity and are shown in Fig. 7.

\begin{tabular}{|c|c|c|c|c|c|c|c|c|c|c|}
\hline \multirow[t]{2}{*}{ Tie-points } & \multicolumn{2}{|c|}{ Depth $(\mathrm{cm})$} & \multicolumn{8}{|c|}{ Age (cal. a BP) } \\
\hline & 204 & 210 & Kane2B & 204 & 210 & Green -Ice & ECPS & HU2008-42 & Median age & Standard deviation \\
\hline I1 & 58 & 28 & 1400 & 1500 & 1550 & 1500 & 1500 & - & 1500 & 55 \\
\hline I2 & 72 & - & 1900 & 1650 & - & 1700 & 1650 & - & 1675 & 119 \\
\hline D1 & 75 & 32 & 1900 & 1850 & 2000 & 2000 & 1900 & 2000 & 1950 & 66 \\
\hline P1 & 114 & 38 & 2500 & 2200 & 2150 & 2400 & 2250 & 2400 & 2325 & 137 \\
\hline I3 & 115 & 40 & 2350 & 2400 & 2300 & 2600 & 2500 & 2550 & 2450 & 118 \\
\hline P2 & 188 & 66 & 3450 & 3500 & 3300 & 3000 & 3500 & 3200 & 3375 & 199 \\
\hline I4 & - & 67 & 3250 & - & 3450 & 3450 & 3400 & 3550 & 3450 & 110 \\
\hline D2 & 198 & 68 & 3400 & 3600 & 3500 & 3750 & 3650 & - & 3600 & 135 \\
\hline I5 & 298 & 96 & 4750 & 4650 & 4600 & 4250 & 4300 & - & 4600 & 222 \\
\hline P3 & 325 & - & 5000 & 5000 & - & 4500 & 4750 & - & 4875 & 239 \\
\hline P4 & 367 & 108 & 5500 & 5450 & 5300 & 5500 & 5450 & - & 5450 & 82 \\
\hline I6 & 390 & 118 & - & 5850 & - & 5800 & 6000 & 6000 & 5925 & 103 \\
\hline D3 & 460 & - & 6450 & 6300 & - & 6250 & 6100 & 6200 & 6250 & 129 \\
\hline P5 & 576 & 213 & - & 7500 & 7200 & 7300 & 7300 & 7200 & 7300 & 122 \\
\hline I7 & - & 280 & - & - & 8250 & 8250 & 8250 & 8200 & 8250 & 25 \\
\hline D4 & - & 295 & 8750 & - & 8600 & 8700 & 8700 & - & 8700 & 63 \\
\hline I8 & - & 360 & - & - & 9000 & 9000 & 9000 & - & 9000 & 0 \\
\hline D5 & - & 365 & - & - & 9000 & 9050 & 9100 & 8900 & 9025 & 85 \\
\hline
\end{tabular}

( $\sim 400$ to $580 \mathrm{~cm}$ ) cannot be established as it lies amongst the unreliable intervals for palaeomagnetic secular variations.

\section{Chronostratigraphy of the northwestern Greenlandmargin}

The sedimentary units described in section 'Lithology' for cores 204, 210 and Kane2B correspond to facies expected in those locations for the Holocene (e.g. Knudsen et al. 2008; St-Onge \& St-Onge 2014; Sheldon et al. 2016). The proposed age models support a correlation with the main chronostratigraphical units previously established for the Holocene (e.g. Walker et al. 2012; International Commission on Stratigraphy) with a subdivision in three distinct periods: Early (Meghalayan), Middle (Northgrippian) and Late(Greenlandian) Holocene, and global boundaries around $\sim 8.2$ cal. ka BP and 4.2 cal. ka BP. However, other studies close to our core locations often observe boundaries around $\sim 7.5$ cal. $\mathrm{ka} \mathrm{BP}$ and $\sim 3.5$ cal. ka BP in their records (e.g. Knudsen et al. 2008; Moros et al. 2016).

In this study, the main units observed in the three cores show a clear boundary between the Early and Middle Holocene ( 8.2-7.5 cal. ka BP), but do not allow us to clearly define the boundary between the Middle and Late Holocene (Fig. 10). Moreover, very little is known about the timing of deglaciation in the Melville Bay region (including the Upernavik Isstrøm region in southern Melville Bay). Although several studies have discussed the onshore geomorphology (Briner et al. 2013), submarine landforms (Dowdeswell et al. 2014; Freire et al. 2015; Slabon et al. 2016; Batchelor et al. 2017; Newton et al. 2017) and ice-sheet dynamics from numerical modelling (e.g. Lecavalier et al. 2014), few geochronological data are available. In this context and based on this new chronostratigraphical framework, a brief account of the main environmental changes is provided below.

Lithofacies 1: Matrix-supported diamicton-deglaciation (Greenlandian). - This lithofacies is only present in cores Kane2B (unit 1, 9.1-9.0 cal. ka BP) and 210 (unit 1, prior to $\sim 9.4$ cal. ka BP, 380-579 $\mathrm{cm}$ ) and corresponds to ice-proximal glaciomarine sedimentation following the retreat of grounded ice. It is a matrix-supported diamicton with the presence of pebbles associated with high magnetic susceptibility (Fig. 10), which indicates ice-rafting, probably a glacigenic debrisflow deposit likely to be related to significant meltwater influxes (Ó Cofaigh et al. 2013; Sheldon et al. 2016). In Kane Basin (Kane2B), this lithofacies probably results from the proximity of both the GIS and IIS to the coring site during this period. The opening of Nares Strait is dated by England et al. (2006) and Jennings et al. (2011) to approximately $\sim 9$ ka BP, which could thus correspond to the base of this core. However, Georgiadis et al. (submitted) suggested that the Kane Basin was not connected to Hall Basin until the retreat of the IIS and GIS from Kennedy Channel around 8.3 cal. ka BP. Thus, we associate this unit to the retreat of the ice sheets from the core location in Kane Basin, but preceding the complete opening of Nares Strait around 8.3 cal. ka BP (Georgiadis et al. submitted).

Likewise, this unit is also associated with the close presence and rapid retreat of the GIS from Melville Bay at the location of core 210. There is evidence for a mid-shelf stabilization, probably during the Younger Dryas fol- 


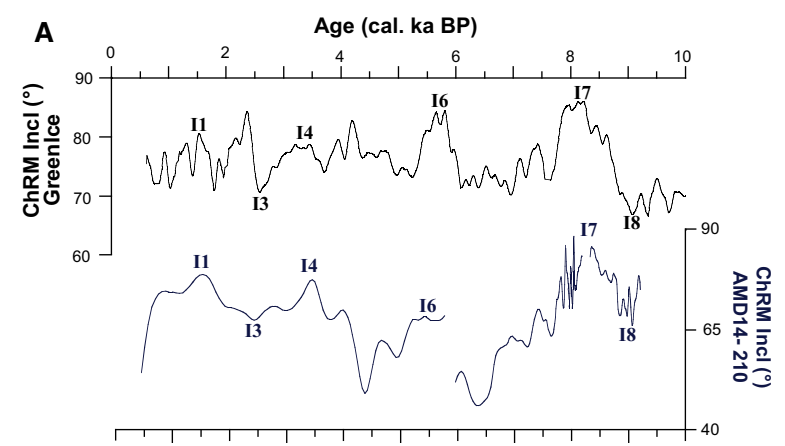

B

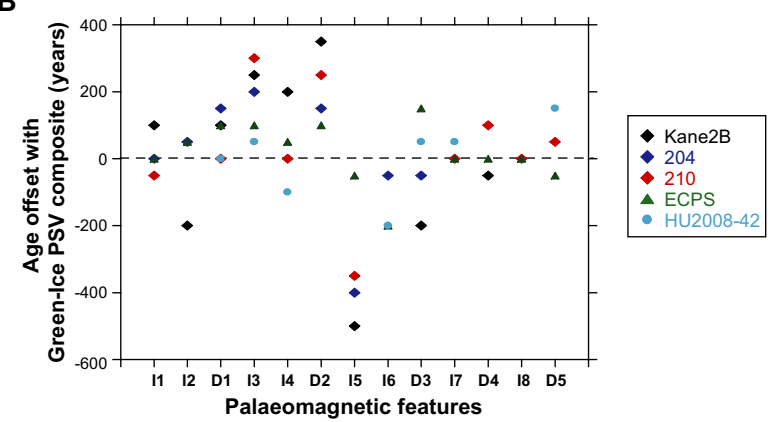

Fig. 8. A. Comparison between inclinations for the Greenland/Iceland composite (Stoner et al. 2013) and core 210 from this study. The main palaeomagnetic features observed in both records are shown, consisting of four inclination highs (I1, I4, I6 and I7) and two inclination lows (I3 and I8). B. Age offset of the palaeomagnetic features established in Fig. 7, between the different records (Kane2B, 204, 210 from this study, ECPS from Barletta et al. 2010 and HU2008-42PC from St-Onge \& StOnge 2014) and the Greenland-Iceland PSV composite (Stoner et al. 2013). ECPS = Eastern Canada Paleostack.

lowed by further retreat on the West Greenland margin (e.g. Slabon et al. 2016; Newton et al. 2017). Studies have shown that the GIS retreated near its current margin inland around $\sim 10.3$ cal. ka BP for the Upernavik Isstrøm region and around $\sim 9.5 \mathrm{cal}$. $\mathrm{ka} \mathrm{BP}$ for the central Melville Bay region (Bennike \& Björck 2002; Bennike 2008; Briner et al. 2013; Young \& Briner 2015). Thus, following the Younger Dryas, we hypothesize that the GIS retreated relatively rapidly from the cross-shelf troughs where cores 204 and 210 are located, respectively, before $\sim 10.3$ cal. ka BP and $\sim 9.5$ cal. ka BP. This statement is supported by the deglacial timing observed here with the established chronology for cores 204 and 210 (Fig. 10). The high clast content found in this unit associated to very variable magnetic susceptibility $\left(\mathrm{k}_{\mathrm{LF}}\right)$ attests to the significant icerafting and meltwater discharge occurring during this interval. This period corresponds to the ice-proximal Early Holocene deglaciation (e.g. Jennings et al. 2014) associated with a low influence of the WGC from 10.2 to 9.2 cal. ka BP (Lloyd et al. 2005) and higher influence of meltwater from the GIS.

Lithofacies 2: Homogeneous clayey silts-Early Holocene, end of deglaciation (Greenlandian). - This lithofacies is characterized by homogeneous clayey silts and corresponds to the establishment of an ice-distal environment dominated by a hemipelagic sedimentation. We found this lithofacies in core 210 (subunit $2 \mathrm{a}$, from $\sim 9.3$ to $8.7 \mathrm{cal}$. ka BP) and 204 (unit 1, from 9.1 to 7.7 cal. ka BP). In core 204 , this facies is marked by high $\mathrm{k}_{\mathrm{LF}}$, but a very low amount of IRD (Fig. 3), which suggests dilution by finer glacial material eroded by a proximal ice stream (Lloyd et al. 2005). It could also be explained by the fact that the GIS was already close to its current margin around 10.3 cal. $\mathrm{ka} \mathrm{BP}$ in the Upernavik Isstrøm region (Briner et al. 2013), and thus delivered a reduced or limited amount of IRD to the nearby margin during this period.

In core 210, located in the Melville Bay cross-shelf trough, this period occurs following ice-proximal conditions. The high clay content, subtle laminations with no grain-size grading and only a few IRDs suggest a deposition of fine suspended sediment, probably from meltwater plumes associated with the further retreat of GIS from the core site. There is no evidence of rapid deposition of this layer, although sedimentation rates are relatively high. We consider this interval as a period of relatively stable conditions reflecting the establishment of ice-distal conditions.

Lithofacies 3: Stratified pebbly mud-Early Holocene, end of deglaciation (Greenlandian). - This lithofacies is characterized by pebbly stratified clayey silts and the dominant deposition mode appears to be hemipelagic, but stratified layers also indicate occasional turbidity current activity in cores 210 and Kane2B (Fig. 3). This lithofacies is found in cores Kane2B (unit 2, from 9.0 to 8.0 cal. ka BP) and 210 (subunit 2b, from 8.7 to 7.5 cal. $\mathrm{ka} \mathrm{BP}$ ) and is probably related to variations (further retreat or re-advance) in the ice sheet's position (Ó Cofaigh et al. 2013; Sheldon et al. 2016). Georgiadis et al. (submitted) suggested that the distinctive rapidly deposited layer present in core Kane2B (300-320 cm) and dated to $\sim 8.3 \mathrm{cal}$. $\mathrm{ka} \mathrm{BP}$ is linked to the collapse of the ice blocking Kennedy Channel and thus marks the complete opening of the Nares Strait. Hence the period from 9.0 to 8.3 cal. ka BP (subunit 2a) probably corresponds to unstable conditions linked with the retreat of both the GIS and IIS from Kane Basin, while the period from 8.3 to 8.0 cal. ka BP (subunit $2 \mathrm{c}$ ) is associated with further retreat of the GIS and IIS after the opening of the Nares Strait. Georgiadis et al. (submitted) also suggested that the connection between Kane Basin and Baffin Bay was limited until after 8.0 cal. ka BP and showed that Kane Basin was a narrow open bay until the opening of Kennedy Channel characterized by the presence of the rapidly deposited layer $(\sim 8.3 \mathrm{cal}$. ka BP).

In core 210, located in the Melville Bay cross-shelf trough, this period corresponds to more unstable conditions with occasional turbidity current activity and IRD from 8.7 to 7.5 cal. ka BP (subunit 2b: characteristic 

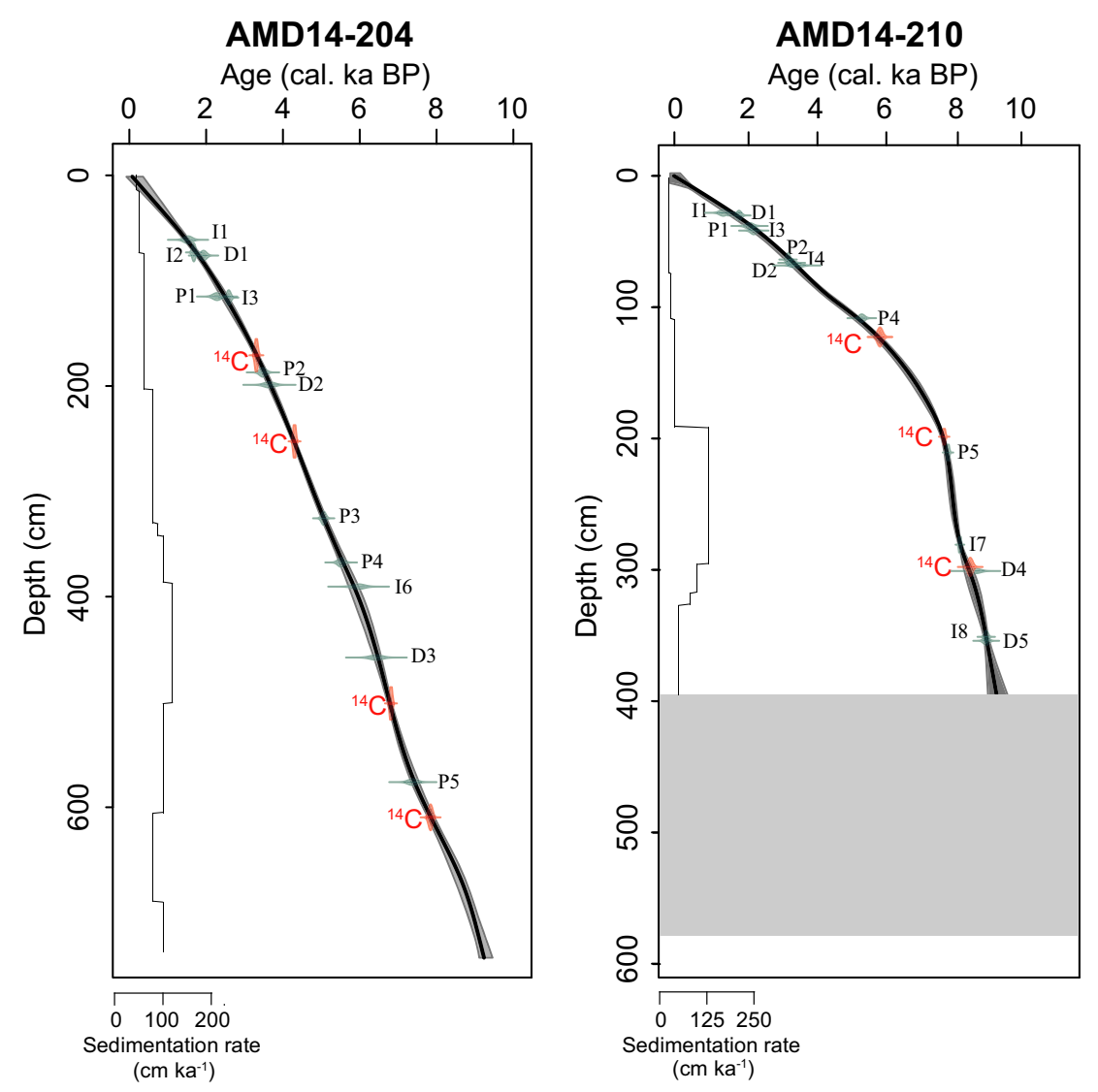

Fig. 9. Composite age models using both the independent ages and palaeomagnetic tie-points (Table 3) for cores 204 and 210 . Age models are constructed using the R-package CLAM (Blaauw 2010). Note that for core 210, the basal layer was not reliable for palaeomagnetic reconstructions.

of lithofacies 2). These unstable conditions might be related to a destabilization of the GIS (re-advances/ retreat), which triggered sediment remobilization in the Melville Bay cross-shelf trough, or simply the presence of down-slope processes, as core 210 site is located in the deepest part of the trough.

Many studies have associated the period from $\sim 10$ to $\sim 8$ cal. ka BP (Early Holocene) with mostly cold surface and sub-surface water conditions as generally linked to the end of the deglaciation (e.g. Jennings et al. 2014; StOnge \& St-Onge 2014; Moros et al. 2016). Thus, in this study, both lithofacies 2 and 3 are associated with the end of the deglaciation and the further retreat of the IIS and GIS on land, close to their modern boundaries.

Lithofacies 4: Homogenous bioturbated mud-Middle to Late Holocene (Northgrippian to Meghalayan). - This lithofacies corresponds to a more ice-distal sedimentation at the core locations with a dominantly hemipelagic mode of deposition. It is also strongly affected by bioturbation, which indicates oceanographic conditions favourable for marine productivity that are coherent with generally warmer conditions as previously inferred (e.g. Levac et al. 2001; Knudsen et al. 2008; St-Onge \& StOnge 2014). For cores Kane2B (unit 3, 8.0 cal. ka BP to present) and 210 (unit 3, 7.5 cal. ka BP to present), this period is characterized by a relatively stable sedimentological environment according to the result presented in this study. These stable sedimentological conditions suggesting optimum environmental conditions are concordant with evidence of improved sea-surface conditions in Kane Basin from 8.0 to 7.0 cal. ka BP onward (Georgiadis et al. submitted).

For core 204 (unit 2,7.7 cal. ka BP to present), a small change occurs around $3.5 \mathrm{ka}$ cal. BP with slightly decreasing values of $\mathrm{k}_{\mathrm{LF}}$, increasing values of $\mathrm{a}^{*}$ (red) and a finer grain size shown by the $\mathrm{k}_{\mathrm{ARM}} / \mathrm{k}_{\mathrm{LF}}$ ratio. These variations support a change in magnetic mineralogy (distinct origin or transport process) probably associated with a dilution of magnetite grains and possibly related to a re-advance of the ice margins at this period (e.g. Moros et al. 2016) and thus, increased ice-rafting linked to icesheet expansion (Ruddiman 1977). In the literature, the period from 7.5 to $3.5 \mathrm{cal}$. ka BP was characterized by relatively warm surface and sub-surface conditions (e.g. Perner et al. 2013; Moros et al. 2016). This period was followed by a cooling and ice-sheet/glacier re-advances with the establishment of the neoglaciation after $3.5 \mathrm{cal}$. ka BP(e.g. Perner et al. 2013; Jennings et al. 2014; Moros et al. 2016). Additionally, a minimum extent of the 


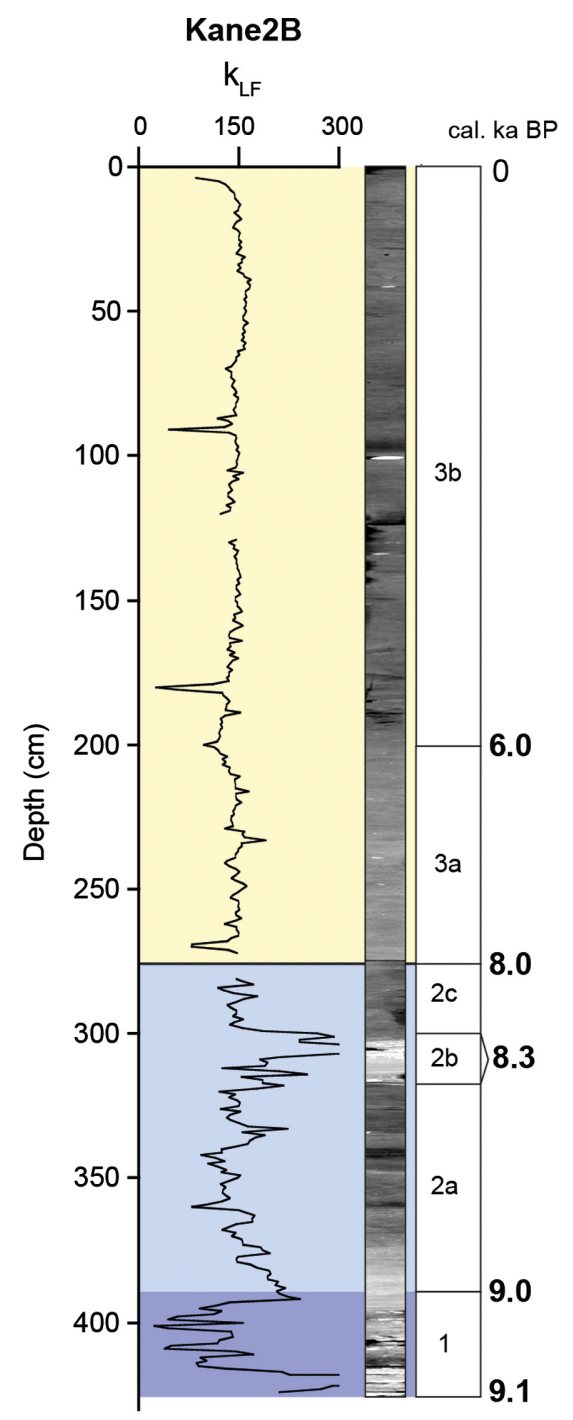

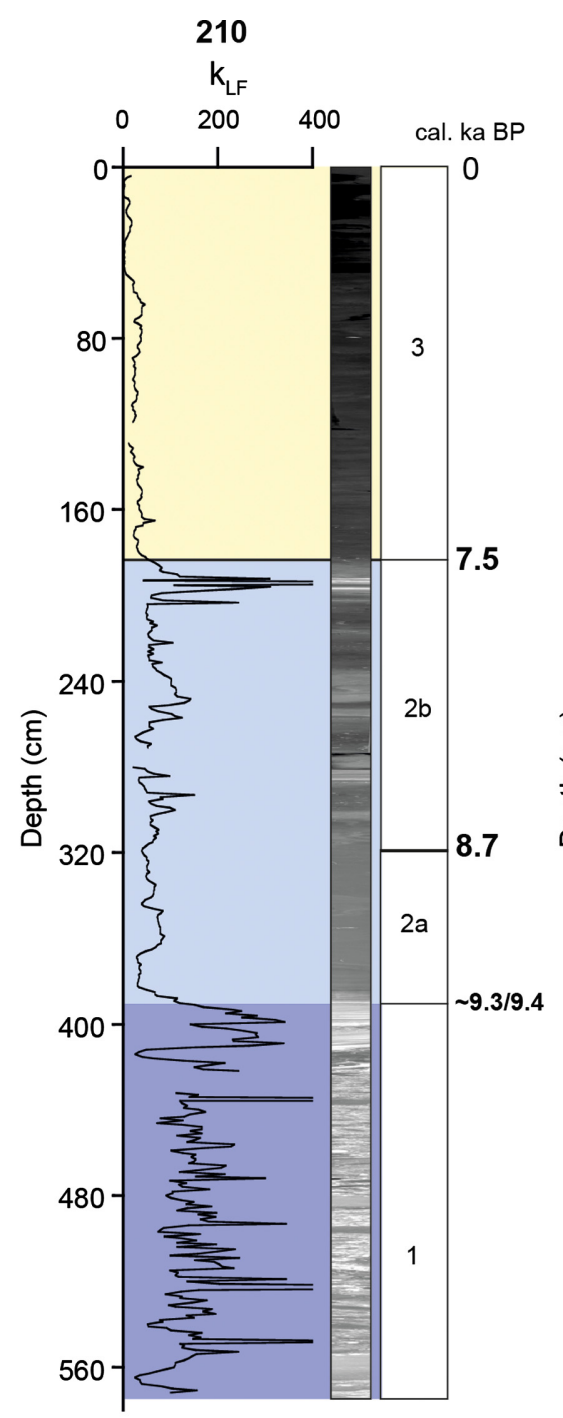
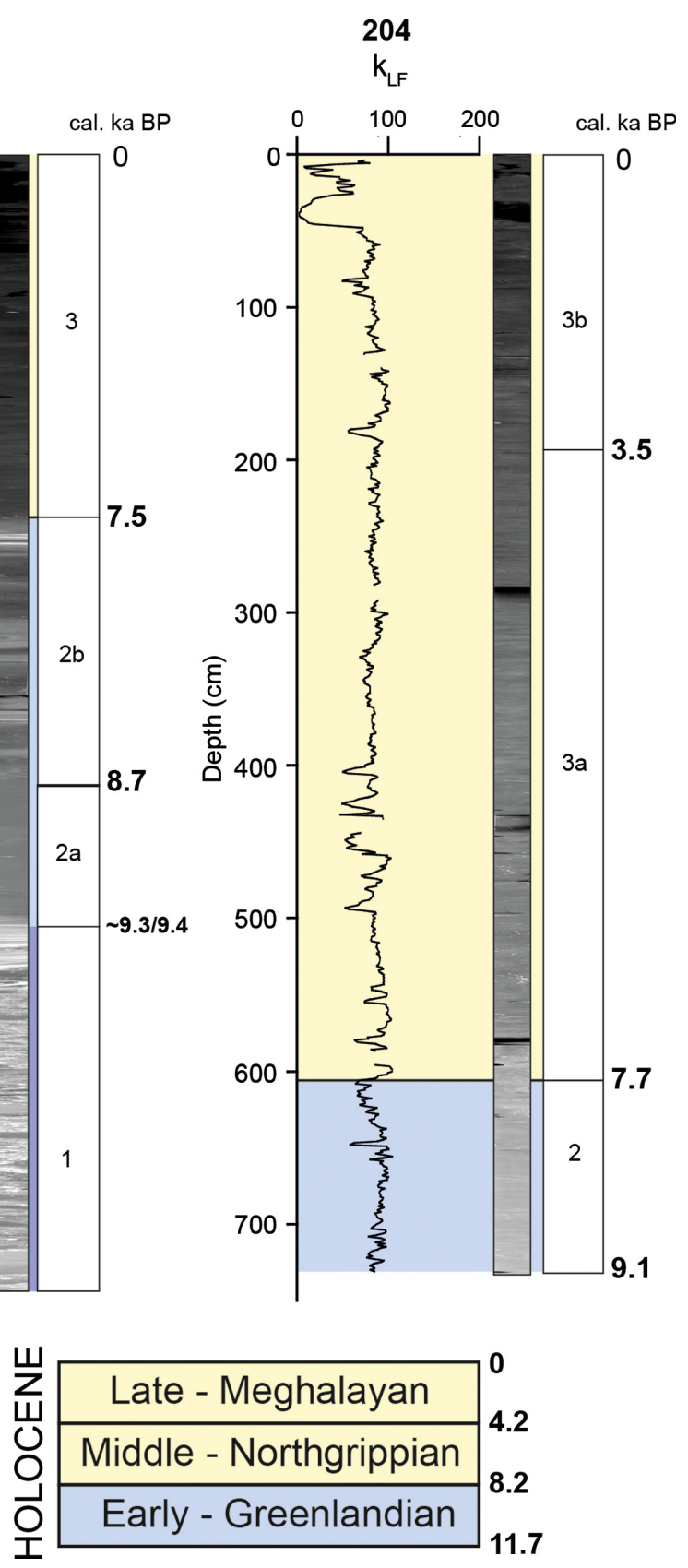

Fig. 10. Comparison of $\mathrm{k}_{\mathrm{LF}}$ for cores Kane2B, 210 and 204 associated to the age (in cal. ka BP) of the different unit limits based on the chronostratigraphy established in this study. The different units are shown, as well as the main Holocene boundaries. (International Commission of Stratigraphy).

western sector of the GIS was observed around 5-3 cal. ka BP (Young \& Briner 2015).

\section{Conclusions}

This paper presents three new, full-vector palaeomagnetic records covering the Holocene in northeastern Baffin Bay. Physical and magnetic properties of the three sedimentary sequences (204, 210 and Kane2B) indicate that the NRM is characterized by a strong, stable and single component magnetization carried by low coercivity ferrimagnetic minerals within the PSD range. This indicates high-quality palaeomagnetic data and allows the reconstruction of reliable palaeomagnetic secular variation and RPI records for most of the three cores. The comparison of these three palaeomagnetic sequences with other palaeomagnetic records and a geomagnetic field model, combined with independent radiocarbon dating, are used for the establishment of the chronostratigraphy for cores 204 and 210. 
This new chronostratigraphical framework provides new minimum constraints on the timing of deglaciation for the northwestern Greenland margin. It confirms that ice retreated prior to $\sim 9.2 \mathrm{cal}$. ka BP in the southern (Upernavik Isstrøm) and central Melville Bay cross-shelf troughs, while it retreated around $9.1 \mathrm{cal}$. $\mathrm{ka}$ BP in the region of Kane Basin (Nares Strait). Although we obtain different ages boundaries than the 8.2 and $4.2 \mathrm{ka} \mathrm{BP}$ global boundaries, the results also support the subdivision of the Holocene into three periods (Early/Greenlandian, Middle/Northgrippian and Late/Meghalayan) with the boundaries between the Early and Middle Holocene ( 7.7/7.5 cal. ka BP for the Melville Bay region and $\sim 8.0$ cal. ka BP for the Kane Basin) well recorded in the three cores. This study highlights an asynchronous deglaciation timing between the Melville Bay/Upernavik Isstrøm and the Kane Basin regions, probably related to different rates of retreat triggered by ice-margin morphology associated with different oceanographic conditions (relatively warm WGC compared to colder water in Kane Basin).

Overall, this chronostratigraphical framework will provide the basis for further palaeoceanographic and palaeoclimate reconstructions in the northeastern Baffin Bay and more specifically in the Nares Strait and Melville Bay regions. Finally, this study highlights the benefits of combining palaeomagnetic and radiocarbon measurements to improve the dating of sedimentary sequences in challenging areas such as Arctic basins.

Acknowledgements. - We are grateful to the captain, officers, crew and scientists on board the CCGS 'Amundsen' during the 2014 ArcticNet (leg 1-b) expedition for the recovery of cores 204, 210 and Kane2B. This study was supported by ArcticNet, the Natural Sciences and Engineering Research Council of Canada (NSERC) through Discovery Grants to G. St-Onge, J.-C. Montero-Serrano and A. Rochon, and the CREATE ArcTrain program through a Ph.D. scholarship to the first author. We thank Joseph Stoner (OSU) for sharing the GreenlandIceland PSV composite record data, as well as Quentin Beauvais and Marie-Pier St-Onge (ISMER) for technical support in the laboratory. Lastly, we thank the editor Jan A. Piotrowski and the two reviewers (Ian Snowball and one anonymous reviewer) for their constructive comments, which helped to improve the manuscript.

\section{References}

Aksu, A. E. 1983: Holocene and Pleistocene dissolution cycles in deepsea cores of Baffin Bay and Davis Strait: palaeoceanographic implications. Marine Geology 53, 331-348.

Aksu, A. E. \& Piper, D. J. W. 1987: Late Quaternary sedimentation in Baffin Bay. Canadian Journal of Earth Science 24, 1833-1846.

Andrews, J. T., Bigg, G. R. \& Wilton, D. J. 2014: Holocene ice-rafting and sediment transport from the glaciated margin of East Greenland $\left(67-70^{\circ} \mathrm{N}\right)$ to the N Iceland shelves: detecting and modelling changing sediment sources. Quaternary Science Reviews 91, 204-217.

Andrews, J. T., Kirby, M., Aksu, A. E., Barber, D. G. \& Meese, D. 1998: Late Quaternary Detrital Carbonate (DC-) layers in Baffin Bay marine sediments $\left(67^{\circ}-74^{\circ} \mathrm{N}\right)$ : correlation with Heinrich events in the North Atlantic. Quaternary Science Reviews 17, 1125-1137.

Antoniades, D., Francus, P., Pienitz, R., St-Onge, G. \& Vincent, W.F. 2011: Holocene dynamics of the Arctic's largest ice shelf. Proceedings of the National Academy of Sciences 108, 18899-18904.
Azetsu-Scott, K., Clarke, A., Falkner, K. K., Hamilton, J., Jones, E. P., Lee, C., Petrie, B., Prinsenberg, S., Starr, M. \& Yeats, P. 2010: Calcium carbonate saturation states in the waters of the Canadian Arctic Archipelago and the Labrador Sea. Journal of Geophysical Research: Oceans 115, C11021, https://doi.org/10.1029/2009JC005917.

Barletta, F., St-Onge, G., Channell, J. E. T. \& Rochon, A. 2010: Dating of Holocene western Canadian Arctic sediments by matching paleomagnetic secular variation to a geomagnetic field model. Quaternary Science Reviews 29, 2315-2324.

Barletta, F., St-Onge, G., Channell, J. E. T., Rochon, A., Polyak, L. \& Darby, D. A. 2008: High-resolution paleomagnetic secular variation and relative paleointensity records from the western Canadian Arctic: implication for Holocene stratigraphy and geomagnetic field behaviour. Canadian Journal of Earth Science 45, 1265-1281.

Batchelor, C. L., Dowdeswell, J. A. \& Rignot, E. 2017: Submarine landforms reveal varying rates and styles of deglaciation in NorthWest Greenland fjords. Marine Geology 402, 60-80.

Beaudoin, A., Pienitz, R., Francus, P., Zdanowicz, C. \& St-Onge, G. 2016: Palaeoenvironmental history of the last six centuries in the Nettilling Lake area (Baffin Island, Canada): a multi-proxy analysis. The Holocene 26, 1835-1846.

Bennike, O. 2008: An early Holocene Greenland whale from Melville Bugt, Greenland. Quaternary Research 69, 72-76.

Bennike, O. \& Björck, S. 2002: Chronology of the last recession of the Greenland Ice Sheet. Journal of Quaternary Science 17, 211219.

Blaauw, M. 2010: Methods and code for 'classical' age-modelling of radiocarbon sequences. Quaternary Geochronology 5, 512-518.

Blott, S. J. \& Pye, K. 2001: Gradistat: a grain size distribution and statistics package for the analysis of unconsolidated sediments. Earth Surface Processes and Landforms 26, 1237-1248.

Briner, J. P., Håkansson, L. \& Bennike, O. 2013: The deglaciation and neoglaciation of Upernavik Isstrøm, Greenland. Quaternary Research 80, 459-467.

Briner, J. P., Michelutti, N., Francis, D. R., Miller, G. H., Axford, Y., Wooller, M. J. \& Wolfe, A. P. 2006: A multi-proxy lacustrine record of Holocene climate change on northeastern Baffin Island, Arctic Canada. Quaternary Research 65, 431-442.

Caricchi, C., Lucchi, R. G., Sagnotti, L., Macrì, P., Morigi, C., Melis, R., Caffau, M., Rebesco, M. \& Hanebuth, T. J. 2018: Paleomagnetism and rock magnetism from sediments along a continental shelf-toslope transect in the NW Barents Sea: implications for geomagnetic and depositional changes during the past 15 thousand years. Global and Planetary Change 160, 10-27.

Channell, J. E. T., Mazaud, A., Sullivan, P., Turner, S. \& Raymo, M. E. 2002: Geomagnetic excursions and paleointensities in the Matuyama Chron at Ocean Drilling Program sites 983 and 984 (Iceland Basin). Journal of Geophysical Research: Solid Earth 107, B6, 2114-2127.

Channell, J. E. T., Stoner, J. S., Hodell, D. A. \& Charles, C. D. 2000 Geomagnetic paleointensity for the last $100 \mathrm{kyr}$ from the subantarctic South Atlantic: a tool for inter-hemispheric correlation. Earth and Planetary Science Letters 175, 145-160.

Dankers, P. 1981: Relationship between median destructive field and remanent coercive forces for dispersed natural magnetite, titanomagnetite and hematite. Geophysical Journal of the Royal Astronomical Society 64, 447-461.

Day, R., Fuller, M. \& Schmidt, V. A. 1977: Hysteresis properties of titanomagnetites: grainsize and compositional dependence. Physics of the Earth and Planetary Interiors 13, 260-267.

Deschamps, C.-E., St-Onge, G., Montero-Serrano, J.-C. \& Polyak, L. 2018: Chronostratigraphy and spatial distribution of magnetic sediments in the Chukchi and Beaufort seas since the last deglaciation. Boreas 47, 544-564.

Dowdeswell, J. A., Hogan, K. A., Ó Cofaigh, C., Fugelli, E. M. G., Evans, J. \& Noormets, R. 2014: Late Quaternary ice flow in a West Greenland fjord and cross-shelf trough system: submarine landforms from Rink Isbrae to Uummannaq shelf and slope. Quaternary Science Reviews 92, 292-309.

Dunlop, D. J. 2002: Theory and application of the Day plot $\left(\mathrm{M}_{\mathrm{rs}} / \mathrm{M}_{\mathrm{s}}\right.$ versus $\mathrm{H}_{\mathrm{cr}} / \mathrm{H}_{\mathrm{c}}$ ). 2. Application to data for rocks, sediments, and soils. 
Journal of Geophysical Research 107, No. B3, 2057, https://doi.org/ 10.1029/2001JB000487.

Dyke, A. S., Andrews, J. T., Clark, P. U., England, J. H., Miller, G. H., Shaw, J. \& Veillette, J. J. 2002: The Laurentide and Innuitian ice sheets during the Last Glacial Maximum. Quaternary Science Reviews 21, 9-31.

England, J. H., Atkinson, N., Bednarski, J., Dyke, A. S., Hodgson, D. A. \& O Cofaigh, C. 2006: The Innuitian Ice Sheet: configuration, dynamics and chronology. Quaternary Science Reviews 25, 689-703.

Fortin, D., Francus, P., Gebhardt, A. C., Hahn, A., Kliem, P. \& LiséPronovost, A. 2013: Destructive and non-destructive density determination: method comparison and evaluation from the Laguna Potrok Aike sedimentary record. Quaternary Science Reviews 71, $147-153$.

Frank, U. \& Nowaczyk, N. R. 2008: Mineral magnetic properties of artificial samples systematically mixed from haematite and magnetite. Geophysical Journal International 175, 449-461.

Freire, F., Gyllencreutz, R., Greenwood, S. L., Mayer, L., Egilsson, A., Thorsteinsson, T. \& Jakobsson, M. 2015: High resolution mapping of offshore and onshore glaciogenic features in metamorphic bedrock terrain, Melville Bay, northwestern Greenland. Geomorphology 250, $29-40$.

Georgiadis, E., Giraudeau, J., Martinez, P., Lajeunesse, P., St-Onge, G., Schmidt, S. \& Massé, G. submitted: Deglacial to postglacial history of Nares Strait, Northwest Greenland: a marine perspective. Climate of the Past Discussions, 1-29, https://doi.org/10. 5194/cp-2018-78.

Grobe, H. 1987: A simple method for the determination of ice-rafted debris in sediment cores. Polarjorschung 57, 123-126.

Hamel, D., de Vernal, A., Gosselin, M. \& Hillaire-Marcel, C. 2002: Organic-walled microfossils and geochemical tracers: sedimentary indicators of productivity changes in the North Water and northern Baffin Bay during the last centuries. Deep-Sea Research Part II: Topical Studies in Oceanography 49, 5277-5295.

Hillaire-Marcel, C. \& de Vernal, A. 2008: Stable isotope clue to episodic sea ice formation in the glacial North Atlantic. Earth and Planetary Science Letters 268, 143-150.

Hiscott, R. N., Aksu, A. E. \& Nielsen, O. B. 1989: Provenance and dispersal patterns, Pliocene-Pleistocene section at site 645, Baffin Bay. Proceedings of the Ocean Drilling Program, Scientific Result 105, 31-52.

Jackson, R., Carlson, A. E., Hillaire-Marcel, C., Wacker, L., Vogt, C. \& Kucera, M. 2017: Asynchronous instability of the North AmericanArctic and Greenland ice sheets during the last deglaciation. Quaternary Science Reviews 164, 140-153.

Jennings, A. E., Sheldon, C., Cronin, T. M., Francus, P., Stoner, J. S. \& Andrews, J. T. 2011: The Holocene history of Nares Strait: transition from glacial bay to Arctic-Atlantic throughflow. Oceanography 24, 162-173.

Jennings, A. E., Walton, M. E., Ó Cofaigh, C., Kilfeather, A., Andrews, J. T., Ortiz, J. D., De Vernal, A. \& Dowdeswell, J. A. 2014: Paleoenvironments during Younger Dryas-Early Holocene retreat of the Greenland Ice Sheet from outer Disko Trough, central west Greenland. Journal of Quaternary Science 29, 27-40.

King, J. W., Banerjee, S. K. \& Marvin, J. 1983: A new rock-magnetic approach to selecting sediments for geomagnetic paleointensity studies: application to paleointensity for the last 4000 years. Journal of Geophysical Research 88, 5911-5921.

Kirschvink, J. L. 1980: The least-squares line and plane and the analysis of palaeomagnetic data. Geophysical Journal International 62, 699-718.

Knudsen, K., Stabell, B., Seidenkrantz, M.-S., Eiríksson, J. \& Blake, W. J. 2008: Deglacial and Holocene conditions in northernmost Baffin Bay: sediments, foraminifera, diatoms and stable isotopes. Boreas 37 , 346-376.

Korte, M., Constable, C., Donadini, F. \& Holme, R. 2011: Reconstructing the Holocene geomagnetic field. Earth and Planetary Science Letters 312, 497-505.

Lecavalier, B. S., Milne, G. A., Simpson, M. J., Wake, L., Huybrechts, P., Tarasov, L., Kjeldsen, K. K., Funder, S., Long, A. J., Woodroffe, S. A., Dyke, A. S. \& Larsen, N. K. 2014: A model of Greenland ice sheet deglaciation constrained by observations of relative sea level and ice extent. Quaternary Science Reviews 102, 54-84.
Levac, E., De Vernal, A. \& Blake, W. J. 2001: Sea-surface conditions in northernmost Baffin Bay during the Holocene: palynological evidence. Journal of Quaternary Science 16, 353-363.

Levi, S. \& Banerjee, S. K. 1976: On the possibility of obtaining relative paleointensities from lake sediments. Earth and Planetary Science Letters 29, 219-226.

Lisé-Pronovost, A., St-Onge, G., Brachfeld, S., Barletta, F. \& Darby, D. 2009: Paleomagnetic constraints on the Holocene stratigraphy of the Arctic Alaskan margin. Global and Planetary Change 68, 85-99.

Lloyd, J., Moros, M., Perner, K., Telford, R. J., Kuijpers, A., Jansen, E. \& McCarthy, D. 2011: A 100 yr record of ocean temperature control on the stability of Jakobshavn Isbrae, West Greenland. Geology 39, 867870

Lloyd, J. M., Park, L. A., Kuijpers, A. \& Moros, M. 2005: Early Holocene palaeoceanography and deglacial chronology of Disko Bugt, West Greenland. Quaternary Science Reviews 24, 1741-1755.

Lund, S., Keigwin, L. \& Darby, D. 2016: Character of Holocene paleomagnetic secular variation in the tangent cylinder: evidence from the Chukchi Sea. Physics of the Earth and Planetary Interiors 256, 49-58.

Maher, B. A. \& Thompson, R. (eds.). 1999: Quaternary Climates, Environments and Magnetism. 390 pp. Cambridge University Press, Cambridge.

Marlowe, J. I. 1966: Mineralogy as an indicator of long-term current fluctuations in Baffin Bay. Canadian Journal of Earth Sciences 3, 191201.

Mazaud, A. 2005: User-friendly software for vector analysis of the magnetization of long sediment cores. Geochemistry, Geophysics, Geosystems 6, Q12006, https://doi.org/10.1029/2005gc001036.

McNeely, R., Dyke, A. S. \& Southon, J. R. 2006: Canadian marine reservoir ages, preliminary data assessment. Geological Survey of Canada, Open File 5049, https://doi.org/10.13140/2.1.1461.6649.

Moros, M., Lloyd, J. M., Perner, K., Krawczyk, D., Blanz, T., de Vernal, A., Ouellet-Bernier, M. M., Kuijpers, A., Jennings, A. E., Witkowski, A., Schneider, R. \& Jansen, E. 2016: Surface and sub-surface multiproxy reconstruction of middle to late Holocene palaeoceanographic changes in Disko Bugt, West Greenland. Quaternary Science Reviews 132, 146-160.

Newton, A. M. W., Knutz, P. C., Huuse, M., Gannon, P., Brocklehurst, S. H., Clausen, O. R. \& Gong, Y. 2017: Ice stream reorganization and glacial retreat on the northwest Greenland shelf. Geophysical Research Letters 44, 7826-7835.

Ó Cofaigh, C., Andrews, J. T., Jennings, A. E., Dowdeswell, J. A., Hogan, K. A., Kilfeather, A. \& Sheldon, C. 2013: Glacimarine lithofacies, provenance and depositional processes on a West Greenland trough-mouth fan. Journal of Quaternary Science 28, $13-26$.

Ó Cofaigh, C., Taylor, J., Dowdeswell, J. A. \& Pudsey, C. J. 2003: Palaeoice streams, trough mouth fans and high-latitude continental slope sedimentation. Boreas 32, 37-55.

Ólafsdóttir, S., Geirsdóttir, Á., Miller, G. H., Stoner, J. S. \& Channell, J. E. T. 2013: Synchronizing Holocene lacustrine and marine sediment records using paleomagnetic secular variation. Geology 41, 535-538.

Opdyke, N. D. \& Henry, K. W. 1969: A test of the dipole hypothesis. Earth and Planetary Science Letters 6, 139-151.

Perner, K., Moros, M., Jennings, A. E., Lloyd, J. M. \& Knudsen, K. L. 2013: Holocene palaeoceanographic evolution off West Greenland. The Holocene 23, 374-387.

Reimer, P. J., Bard, E., Bayliss, A., Beck, J. W., Blackwell, P. G., Bronk Ramsey, C., Buck, C. E., Edwards, R. L., Friedrich, M., Grootes, P. M., Guilderson, T. P., Haflidason, H., Hajdas, I., Hatté, C., Heaton, T. J., Hogg, A. G., Hughen, K. A., Kaiser, K. F., Kromer, B., Manning, S. W., Reimer, R. W., Richards, D. A., Scott, E. M., Southon, J. R., Turney, C. S. M. \& van der Plicht, J. 2013: IntCal13 and MARINE13 radiocarbon age calibration curves $0-50,000$ years cal BP. Radiocarbon 55, 1869-1887.

Ruddiman, W. F. 1977: Late Quaternary deposition of ice-rafted sand in the subpolar North Atlantic Ocean. Geological Society of America Bulletin 88, 1813-1827.

Sadler, H. E. 1976: Water, heat, and salt transports through Nares Strait, Ellesmere Island. Journal of the Fisheries Board of Canada 33 , 2286-2295. 
Sagnotti, L., Macrì, P., Lucchi, R., Rebesco, M. \& Camerlenghi, A. 2012: A Holocene paleosecular variation record from the northwestern Barents Sea continental margin. Geochemistry, Geophysics, Geosystems 12, Q11Z33, https://doi.org/10.1029/2011GC003810.

Sheldon, C., Jennings, A., Andrews, J. T., Ó Cofaigh, C., Hogan, K., Dowdeswell, J. A. \& Seidenkrantz, M. S. 2016: Ice stream retreat following the LGM and onset of the west Greenland current in Uummannaq Trough, west Greenland. Quaternary Science Reviews $147,27-46$

Simon, Q., Hillaire-Marcel, C., St-Onge, G. \& Andrews, J. T. 2014 North-eastern Laurentide, western Greenland and southern Innuitian ice stream dynamics during the last glacial cycle. Journal of Quaternary Science 29, 14-26.

Simon, Q., St-Onge, G. \& Hillaire-Marcel, C. 2012: Late Quaternary chronostratigraphic framework of deep Baffin Bay glaciomarine sediments from high-resolution paleomagnetic data. Geochemistry, Geophysics, Geosystems 13, Q0AO03, https://doi.org/10.1029/ 2012GC004272.

Simon, Q., Thouveny, N., Bourlès, D. L., Nuttin, L., Hillaire-Marcel, C. \& St-Onge, G. 2016: Authigenic ${ }^{10} \mathrm{Be} /{ }^{9} \mathrm{Be}$ ratios and ${ }^{10} \mathrm{Be}$-fluxes $\left({ }^{230} \mathrm{Th}_{\mathrm{xs}}\right.$-normalized $)$ in central Baffin Bay sediments during the last glacial cycle: paleoenvironmental implications. Quaternary Science Reviews 140, 142-162.

Slabon, P., Dorschel, B., Jokat, W., Myklebust, R., Hebbeln, D. \& Gebhardt, C. 2016: Greenland ice sheet retreat history in the northeast Baffin Bay based on high-resolution bathymetry. Quaternary Science Reviews 154, 182-198.

Snowball, I. \& Sandgren, P. 2004: Geomagnetic field intensity changes in Sweden between 9000 and $450 \mathrm{cal} \mathrm{BP}$ : extending the record of "archaeomagnetic jerks" by means of lake sediments and the pseudoThellier technique. Earth and Planetary Science Letters 227, 361376.

Snowball, I., Zillén, L., Ojala, A., Saarinen, T. \& Sandgren, P. 2007: FENNOSTACK and FENNORPIS: Varve dated Holocene palaeomagnetic secular variation and relative palaeointensity stacks for Fennoscandia. Earth and Planetary Science Letters $255,106-116$.

Stoner, J. S. \& St-Onge, G. 2007: Magnetic stratigraphy in paleoceanography: reversals, excursions, paleointensity, and secular variation. Developments in Marine Geology 1, 99-138.

Stoner, J. S., Channell, J. E. T., Hillaire-Marcel, C. \& Kissel, C. 2000: Geomagnetic paleointensity and environmental record from Labrador Sea core MD95-2024: global marine sediment and ice core chronostratigraphy for the last $110 \mathrm{kyr}$. Earth and Planetary Science Letters 183, 161-177.

Stoner, J. S., Channell, J. E., Mazaud, A., Strano, S. E. \& Xuan, C. 2013: The influence of high-latitude flux lobes on the Holocene paleomagnetic record of IODP Site U1305 and the northern North Atlantic. Geochemistry, Geophysics, Geosystems 14, 4623-4646.

Stoner, J. S., Jennings, A. E., Kristja, B. \& Dunhill, G. 2007: A paleomagnetic approach toward refining Holocene radiocarbonbased chronologies: paleoceanographic records from the north Iceland (MD99-2269) and east Greenland (MD99-2322) margins. Paleoceanography 22, 1-23.

St-Onge, G. \& Long, B. F. 2009: CAT-scan analysis of sedimentary sequences: an ultrahigh-resolution paleoclimatic tool. Engineering Geology 103, 127-133.

St-Onge, M. P. 2012: Reconstitutions paléoenvironnementales et paléomagnétiques à haute résolution de séquences sédimentaires provenant de la baie de Baffin. M.Sc. thesis. Université du Québec à Rimouski.

St-Onge, M. P. \& St-Onge, G. 2014: Environmental changes in Baffin Bay during the Holocene based on the physical and magnetic properties of sediment cores. Journal of Quaternary Science 29, 41-56.
St-Onge, G., Chapron, E., Mulsow, S., Salas, M., Viel, M., Debret, M., Foucher, A., Mulder, T., Winiarski, T., Desmet, M., Costa, P. J. M., Ghaleb, B., Jaouen, A. \& Locat, J. 2012: Comparison of earthquaketriggered turbidites from the Saguenay (Eastern Canada) and Reloncavi (Chilean margin) Fjords: implications for paleoseismicity and sedimentology. Sedimentary Geology 243-244, 89-107.

St-Onge, G., Mulder, T., Francus, P. \& Long, B. 2007: Continuous physical properties of cored marine sediments. Developments in Marine Geology 1, 63-98.

St-Onge, G., Stoner, J. S. \& Hillaire-Marcel, C. 2003: Holocene paleomagnetic records from the St. Lawrence Estuary, eastern Canada: centennial- to millennial-scale geomagnetic modulation of cosmogenic isotopes. Earth and Planetary Science Letters 209, 113-130.

Stuiver, M., Reimer, P. J. \& Reimer, R. W. 2017: CALIB 7.1. Available at: http://calib.org (accessed 18.10.2017).

Tang, C. C. L., Ross, C. K., Yao, T., Petrie, B., DeTracey, B. M. \& Dunlap, E. 2004: The circulation, water masses and sea-ice of Baffin Bay. Progress in Oceanography 63, 183-228.

Tauxe, L. 1993: Sedimentary records of relative paleointensity of the geomagnetic field: theory and practice. Reviews of Geophysics 31, 319-354.

Tauxe, L. \& Wu, G. 1990: Normalized remanence in sediments of the western equatorial Pacific: relative paleointensity of the geomagnetic field? Journal of Geophysical Research: Solid Earth 95, 12337-12350.

Tauxe, L., Mullender, T. A. T. \& Pick, T. 1996: Potbellies, wasp-waists, and superparamagnetism in magnetic hysteresis. Journal of Geophysical Research 101, 571-583.

Tauxe, L., Pick, T. \& Kok, Y. S. 1995: Relative paleointensity in sediments: a Pseudo-Thellier Approach. Geophysical Research Letters 22, 2885-2888.

Valet, J. P. \& Meynadier, L. 1998: A comparison of different techniques for relative paleointensity. Geophysical Research Letters 25, 89-92.

de Vernal, A., Bilodeau, G., Hillaire-Marcel, C. \& Kassou, N. 1992: Quantitative assessment of carbonate dissolution in marine sediments from foraminifer linings vs. shell ratios: Davis Strait, northwest North Atlantic. Geology 20, 527-530.

de Vernal, A., Hillaire-Marcel, C., Aksu, A. E. \& Mudie, P. 1987: Palynostratigraphy and chronostratigraphy of Baffin Bay deep sea cores: climatostratigraphic implications. Palaeogeography, Palaeoclimatology, Palaeoecology 61, 97-105.

Walczak, M. H., Stoner, J. S., Mix, A. C., Jaeger, J., Rosen, G. P., Channell, J. E. T., Heslop, D. \& Xuan, C. 2017: A 17,000 yr paleomagnetic secular variation record from the southeast Alaskan margin: regional and global correlations. Earth and Planetary Science Letters 473, 177-189.

Walker, M. J., Berkelhammer, M., Björck, S., Cwynar, L. C., Fisher, D. A., Long, A. J., Lowe, J. J., Newnham, R. M., Rasmussen, S. O. \& Weiss, H. 2012: Formal subdivision of the Holocene Series/Epoch: a discussion paper by a working group of INTIMATE (Integration of ice-core, marine and terrestrial records) and the subcommission on Quaternary Stratigraphy (International Commission on Stratigraphy). Journal of Quaternary Science 27, 649-659.

Weeks, R., Laj, C., Endignoux, L., Fuller, M., Roberts, A., Manganne, R., Blanchard, E. \& Goree, W. 1993: Improvements in long-core measurement techniques: applications in palaeomagnetism and palaeoceanography. Geophysical Journal International 114, 651662.

Young, N. E. \& Briner, J. P. 2015: Holocene evolution of the western Greenland Ice Sheet: assessing geophysical ice-sheet models with geological reconstructions of ice- margin change. Quaternary Science Reviews 114, 1-17.

Zijderveld, J. D. A. 1967: A.C. demagnetization of rocks: analysis of results. In Collinson, D. W., Creer, K. M. \& Runcorn, S. K. (eds.): Methods in Paleomagnetism, 254-286. Elsevier, New York. 